Research

Southern

Africa

\title{
Monetary policy and inflation in South Africa: A VECM augmented with foreign variables
}

\author{
Annari de Waal and Reneé van Eyden \\ ERSA working paper 316 \\ http://econrsa.org/home/index.php?option=com_docman\&task=doc_download\&gid=494\&ltemid=67
}

October 2012

Economic Research Southern Africa (ERSA) is a research programme funded by the National Treasury of South Africa.

The views expressed are those of the author(s) and do not necessarily represent those of the funder, ERSA or the author's affiliated institution(s). ERSA shall not be liable to any person for inaccurate information or opinions contained herein. 


\title{
Monetary policy and inflation in South Africa: A VECM augmented with foreign variables
}

\author{
Annari de Waal*and Reneé van Eyden ${ }^{\dagger}$
}

October 17, 2012

\begin{abstract}
We develop a structural cointegrated vector autoregressive (VAR) model with weakly exogenous foreign variables, suitable for a small open economy like South Africa. This type of model is known as an augmented vector error correction model (VECM), referred to by VECX*. We compile the foreign variables with trade-weighted three-year moving average data for 32 countries, to account for the significant change in trade shares over time. This model is novel for South Africa, in two ways: it is the first $\mathrm{VECX}^{*}$ developed to analyse monetary policy in the country and the first model that uses time-varying trade weights for the creation of the foreign series. We find three significant long-run economic relations: the augmented purchasing power parity, the uncovered interest parity and the Fisher parity. These long-run relations are imposed on the VECX* to investigate the effect of a monetary policy shock on inflation. The results suggest the effective functioning of the monetary transmission mechanism in South Africa.
\end{abstract}

JEL Classification: C50, E52

Keywords: South Africa, monetary policy, structural cointegrated vector autoregressive model, augmented VECM, VECX*

\section{Introduction}

South Africa adopted inflation targeting as its primary tool of monetary policy in 2000. To date the South African Reserve Bank (SARB) remains committed to inflation targeting to ensure long-run price stability. In a letter from Finance Minister Pravin Gordhan to SARB Governor Gill Marcus, dated 16 February 2010, Minister Gordhan states that "the Bank should continue to pursue a

\footnotetext{
* Lecturer in the Department of Economics, University of Pretoria, South Africa. Email: annari.dewaal@up.ac.za Annari de Waal acknowledges financial support from the Commonwealth Scholarship Commission in the UK and the Cambridge Commonwealth Trust. We are grateful to Professor M. Hashem Pesaran and participants of the Economic Society of South Africa (ESSA) Conference in September 2011 for helpful comments and suggestions.

${ }^{\dagger}$ Associate professor in the Department of Economics, University of Pretoria.
} 
target of 3 to 6 per cent for headline CPI inflation" (Gordhan, 2010). He highlights the importance of maintaining low inflation - that it supports sustainable growth and employment, and that it protects the living standards of people in the country.

An investigation of the effectiveness of the monetary transmission mechanism is thus still important to ensure appropriate policy actions in South Africa. It is not sufficient to know only the direction of change in variables following a change in monetary policy (Bain \& Howells, 2003). It is also important that policy makers take into account the time lag between a change in the official interest rate (the repo rate) and its impact on aggregate output and inflation, as well as the magnitude of changes in output and inflation. Mishkin (1995) names these elements the "timing and effect" of monetary policies on the economy.

Time lags tend to differ from country to country due to differences in economic and financial market structures (Casteleijn, 2001). Bain and Howells (2003) note that for industrialised countries, the lag between a change in the official interest rate and its full impact on demand and production is normally about 12 months. The lag between the interest rate change and the full impact on inflation is 24 months, thus a further 12 months. Research by the SARB, performed more than a decade ago, confirmed these time lags for South Africa (Smal \& De Jager, 2001). As far as we know, this is the only complete study of the transmission of monetary policy for South Africa. The authors do not provide details to replicate their small macroeconometric model.

Our objective is to develop a suitable topical model for analysing the transmission of monetary policy changes to inflation in South Africa. The model must include a foreign component, since South Africa is a small open economy. Previous macroeconometric models for South African use either United States data as a proxy for the rest of the world or they use fixed trade weights to weigh data of the main trading partners. Due to substantial changes in the trade shares of South Africa's key trading partners, we argue that the incorporation of foreign variables created using time-varying trade-weighted data is more accurate.

Figure 1 illustrates the considerable change in the trade shares of South Africa's 15 most important trading partners between 1980 and $2009^{1}$. Trade with China increased from none before 1993 to a three-year moving average of 14 per cent in 2009. China became the largest trading partner of South Africa in 2009 (overtaking Germany's position). Trade with the UK, USA, Japan and the Euro area generally decreased in the last few decades.

Figure 2 shows the combined trade share of the eight Euro countries included in the model (Austria, Belgium, Finland, France, Germany, Italy, Netherlands and Spain) with South Africa, highlighting the declining trade with these countries.

To account for the significant changes in trade shares, we use time-varying trade weights for 32 countries $^{2}$ to create the foreign variables in our model.

\footnotetext{
${ }^{1}$ The data are from the Global VAR (GVAR) Toolbox 1.1 dataset (Smith \& Galesi, 2011)

${ }^{2}$ The 32 countries account for 77 per cent of South Africa's average trade between 2006 and
} 
We develop a structural vector error correction model (VECM) with weakly exogenous (X) foreign $(*)$ variables (Pesaran, Shin \& Smith, 2000; Pesaran \& Shin, 2002; Garratt, Lee, Pesaran \& Shin, 2003; Garratt, Lee, Pesaran \& Shin, 2006). This type of model, which is suitable for a small open economy such as South Africa, is referred to by VECX*. Applications of VECX* in the literature include models for the UK (Garratt et al., 2003), Thailand (Akusuwan, 2005), Indonesia (Affandi, 2007) and Switzerland (Assenmacher-Wesche \& Pesaran, 2008; 2009).

To our knowledge, this is the first VECX* developed to analyse the transmission of monetary policy in the country. De Wet, Van Eyden and Gupta (2009) developed a VECM model for South Africa using part of the framework suggested in earlier Global VAR (GVAR) studies. Their model has a different purpose of investigating portfolio risk and it is not comparable to the VECX* models listed below since it did not utilise the Garratt et al. (2006) framework.

The next section provides more information on the literature consulted, while Section 3 briefly outlines the VECX* methodology. Sections 4,5 and 6 respectively provide information on the data used, analysis of the data and the VECX* model results. We conclude with a summary and a discussion of further research.

\section{Literature review}

VECX* models are also classified as cointegrating VARX or cointegrating VARX* models (Affandi, 2007; Garratt et al., 2006). These models were introduced and further developed by Pesaran et al. (2000), Pesaran and Shin (2002) and Garratt et al. (2003), with a detailed explanation of the methodology in Garratt et al. (2006). Pesaran et al. (2000) explain that the models are particularly suitable for small open economies due to the handling of foreign variables as weakly exogenous. Pesaran and Smith (2006) further illustrate that this type of model can be derived as the solution to an open macro economy New Keynesian Dynamic Stochastic General Equilibrium (DSGE) model, thereby underpinning the long-run relations considered in the VECX* model.

Therefore, the advantage of using a VECX* approach for South Africa is that the model accounts for long-run theoretical relations and short-run properties, which are both important in the analysis of the impact of monetary policy shocks on the system. Secondly, the inclusion of weakly exogenous foreign variables, which is relevant for a small open economy such as South Africa, is possible in a VECX* model. The inclusion of foreign variables also enables analysis of the impact of a global shock on the transmission of monetary policy in South Africa. Another advantage of developing a VECX* model for South Africa is that it can be incorporated directly into a GVAR model, where all the foreign variables are determined endogenously. Pesaran, Schuermann and Weiner (2004) first suggested the GVAR framework.

2010. These countries were included to align the model with the 33 countries (South Africa and 32 other countries) included in the Global VAR (GVAR) Toolbox 1.1 dataset(Smith \& Galesi, 2011) 
Finally, the VECX* model for South Africa and its inclusion into a GVAR model could be a useful addition to the suite of econometric models of the SARB. The models currently used by the SARB include a core model (SARB, 2007), a small-scale macroeconometric model, VAR models, VECMs, Phillips-curve models, indicator models and structural VAR models (Casteleijn, 2001). More recently, the SARB has developed quarterly projection models (QPMs) and dynamic stochastic general equilibrium (DSGE) models, including a steady state QPM for the country (De Jager, 2007), a New Keynesian DSGE model for South Africa (Steinbach, Mathuloe \& Smit, 2009) and a Small Open Economy New Keynesian DSGE-VAR (SOENKDSGE-VAR) model for South Africa (Gupta \& Steinbach, 2010). The SARB draws on these models for various purposes, including forecasting and simulations. None of these models includes time-varying trade-weighted foreign variables. We showed in Section 1 that the incorporation of time-varying weights in an open economy model for South Africa (as in our VECX* model) is important due to substantial changes in the trade weights of South Africa's main trading partners over time.

The first VECX* model was developed by Garratt et al. (2003) for the UK economy. Further VECX* models followed for Thailand (Akusuwan, 2005), Indonesia (Affandi, 2007) and Switzerland (Assenmacher-Wesche \& Pesaran, 2008; 2009). The countries considered in these papers are small open economies such as South Africa. In addition, the UK and Thailand are full-fledged inflationtargeting countries like South Africa. Indonesia is categorised as an inflationtargeting "lite" country, while Switzerland follows implicit inflation targeting. Due to the similarities, all the above studies are relevant to this VECX* model for South Africa. Since South Africa is an emerging market economy, we pay particular attention to the models developed for Thailand and Indonesia. Each of the previous VECX* ${ }^{*}$ studies effectively explores the monetary policy transmission process in the country considered, which is the objective of this paper. In addition, the models are successful in forecasting inflation.

Regarding our aim to investigate the impact of monetary policy shocks on inflation in South Africa, to our knowledge the only complete published investigation of the transmission of monetary policy in South Africa is by Smal and De Jager (2001) from the SARB. The authors analyse the monetary transmission mechanism in South Africa with a small-scale macroeconometric model. They discuss monetary policy in the country since the 1980s, before investigating the various transmission mechanisms, or channels, through which changes in monetary policy affect the real economy and inflation in a country. The channels, as classified by Mishkin (1995), are the interest rate channel, other asset price channels (exchange rate and equity prices) and the credit channel (bank-lending channel and balance-sheet channel $)^{3}$. Their model incorporates these channels to explore the lags involved in the transmission of monetary policy in South Africa. The authors provide no specific details of the model used, but they do clarify the two scenarios used to shock the system to determine the lags involved.

\footnotetext{
${ }^{3}$ See Appendix $\mathrm{C}$ for a full discussion of the channels of the monetary transmission mechanism.
} 
These scenarios are an increase in the repo rate (providing for the real exchange rate to be affected by the interest rate differential and purchasing power parity) and a change in the repo rate with a Taylor-type monetary policy reaction function added to the model (which will further allow the repo rate to adjust to domestic output and inflation). Smal and De Jager (2001) confirm the time lag between a change in the official interest rate and the full impact on demand and production, which is real economic activity, as approximately 12 months. The authors verify the lag between a change in monetary policy and the full impact on domestic inflation as approximately 24 months, thus a further 12 months, but they caution that the lags are dependent on the prevailing factors. Our model accounts for the traditional interest rate channel and the exchange rate channel of the monetary transmission mechanism, using the Mishkin (2004) classification. According to the traditional interest rate channel, expansionary monetary policy (a decrease in the official rate) will cause other interest rates to decrease. Lower interest rates will increase consumption and fixed investment. As a result, real output will increase. According to the exchange rate channel, expansionary monetary policy will lower domestic interest rates compared to foreign interest rates. The exchange rate will depreciate, leading to higher net exports and thus higher real output.

For the SARB, the core model ["a medium-sized Type II hybrid model", (2007)], the QPM model (De Jager, 2007) and the New Keynesian DSGE model (Steinbach et al., 2009) all include monetary policy transmission channels. The authors note that the models' responses to shocks illustrate the correct functioning of the monetary transmission mechanism in South Africa, but they do not provide a clear indication of the time lags and magnitude of changes following a monetary policy shock.

This paper thus adds to the literature by developing a VECX* for South Africa that includes time-varying trade-weighted foreign variables to account for the substantial change in the trade shares of the key trading partners over time. In addition, it provides a more recent view of the transmission of monetary policy in South Africa.

\section{$3 \quad \mathrm{VECX}^{*}$ methodology}

The VECX* approach is documented in Garratt et al. (2006). We provide a brief summary of the methodology here.

Hendry and Richard (1983) refer to weakly exogenous explanatory variables as regressors that are uncorrelated with the stochastic error term. The definition of weakly exogenous variables in the VECX* framework is different. The sub-system VECM models (named marginal models) for the weakly exogenous foreign variables do not contain the cointegrating vectors of the overall VECX* model (Pesaran et al., 2000). This assumption is necessary for modelling a small open economy, such as South Africa.

A vector of endogenous and exogenous $I(1)$ variables, $z_{t}$, can be written as $z_{t}=\left(y_{t}^{\prime}, x_{t}^{\prime}\right)$, with $y_{t}$ a vector of endogenous $I(1)$ variables (the domestic 
variables and $x_{t}$ a vector of exogenous $I(1)$ variables (the foreign variables). Assume now that $x_{t}$ is weakly exogenous (also known as long-run forcing for $\left.y_{t}\right)$ in the long-run multiplier matrix $\Pi$ of a normal VECM. This assumption corresponds to $\Pi_{x}=0$, where $\Pi$ is separated as $\Pi^{\prime}=\left(\Pi_{x}^{\prime}, \Pi_{y}^{\prime}\right)$. This means that the domestic endogenous variables do not have an impact on the foreign exogenous variables in the long term, since the domestic economy is small and open.

The $\mathrm{VECX}^{*}$ model can be represented by

$$
\Delta \mathbf{y}_{t}=-\boldsymbol{\Pi}_{y} \mathbf{z}_{t-1}+\Lambda \Delta \mathbf{x}_{t}+\sum_{i=1}^{p-1} \boldsymbol{\Psi}_{i} \Delta \mathbf{z}_{t-i}+\mathbf{c}_{0}+\mathbf{c}_{1} t+\boldsymbol{\nu}_{t}
$$

with the marginal equations for the weakly exogenous variables identified as

$$
\Delta \mathbf{x}_{t}=\sum_{i=1}^{p-1} \boldsymbol{\Gamma}_{x i} \Delta \mathbf{z}_{t-i}+\mathbf{a}_{x 0}+\mathbf{u}_{x t}
$$

\section{Data}

The VECX* model for South Africa incorporates quarterly domestic and timevarying trade-weighted foreign data from 1979 Q2 to 2009 Q4. Except for domestic broad money supply (M3), the data used is from the GVAR Toolbox 1.1 dataset (Smith \& Galesi, 2011), which includes data for 33 countries accounting for about 90 per cent of world output. Appendix A describes the data sources and it provides information regarding the creation of the domestic and foreign variables.

\section{Data analysis}

In the remainder of this paper, we follow the modelling approach used by Assenmacher-Wesche and Pesaran (2009) in their development of a VECX* model for Switzerland.

The long-run economic relations that we consider for South Africa are the purchasing power parity (PPP), the uncovered interest parity that relates domestic and foreign interest rates (UIP), the Fisher parity that links the domestic interest rate to domestic inflation (LIR), a money demand relationship (MD) and a connection between domestic and foreign output (GAP). These long-run relations are included in the $\mathrm{VECX}^{*}$ literature. Table 1 shows which of these five long-run relations hold in the cases of Switzerland (Assenmacher-Wesche \& Pesaran, 2009), Thailand (Akusuwan, 2005) and Indonesia (Affandi, 2007), based on the autoregressive distributed lag (ARDL) or bounds testing approach to cointegration (Pesaran \& Shin, 1999; Pesaran, Shin \& Smith, 2001). One of the advantages of the ARDL approach is that it is not necessary to know whether variables are $I(0)$ or $I(1)$, i.e. stationary or non-stationary. 
The domestic variables needed to test these relationships are the nominal effective exchange rate $(e)$, prices $(p)$, the repo rate $(r)$, the quarterly inflation rate $(\pi)$, real M3 $(m 3)$ and real output $(y)$. The foreign variables used are foreign prices $\left(p^{*}\right)$, foreign real output $\left(y^{*}\right)$ and the foreign short-term interest rate $\left(r^{*}\right)$.

We first investigate the potential long-term relations graphically. Theoretically, the PPP suggests that domestic and foreign prices calculated in the same currency will be in equilibrium in the long term due to global trade. Due to the large correlation between the exchange rate $(e)$ and the output gap $\left(y-y^{*}\right)$, observed in Table 7 in Appendix A, we explore both $\operatorname{PPP}\left(p-p^{*}-e\right)$ and $\operatorname{PPP}^{A}$, augmented purchasing power parity, $\left(e-\left(p-p^{*}\right)-\beta_{1}\left(y-y^{*}\right)\right)$. Figure 3 and Figure 4 show the movement in exchange rates against the ratio of domestic and foreign prices and the ratio of domestic and foreign output respectively, both in levels and in first differences. The exchange rate and the ratio of domestic to foreign prices have the same trend in the long term, suggesting that the PPP may hold for South Africa. The negative relationship between the exchange rate and the ratio of domestic to foreign output is only evident up to 2000. It is therefore not clear whether the $\mathrm{PPP}^{A}$ will be relevant for South Africa.

The UIP implies that the arbitrage process between domestic and foreign bonds will ensure that domestic and foreign interest rates will be in equilibrium in the long term. Figure 5 illustrates domestic and foreign short-term interest rates, first in levels and then in first differences.

The short-term interest rates seem to have similar patterns over time, indicating that the UIP may hold for South Africa. The large gap between domestic and foreign rates is in line with expectations, since South Africa is a developing country and the higher interest rate rewards investors for the risk faced.

For the connection between the domestic interest rate and domestic inflation (LIR), we consider the modified Fisher parity $\left(r-\beta_{2} \pi\right)$ in addition to the usual Fisher parity $(r-\pi)$. Figure 6 shows this link, again in both levels and first differences. Interest rates and inflation seem to have the same long-term trends.

For the money demand (MD) connection defined in Table $1, m-\beta_{3} y-$ $\beta_{4} r, \beta_{3}$ (the income elasticity) is expected to be positive and $\beta_{4}$ (the interest rate elasticity) is expected to be negative. Figure 7 and Figure 8 confirm the anticipated relationships of money with output and interest rates respectively. The negative link between money and interest rates is only valid from late 1998 onwards.

According to output convergence (GAP in Table 1), domestic and foreign output should converge in the long run. Figure 9, which includes the levels and first differences of domestic and foreign output, suggests that this relation may hold from 1994 onwards.

We use the ARDL cointegration approach (Pesaran \& Shin, 1999; Pesaran et al., 2001) to determine whether the above long-run relations are valid. Table 2 summarises the formal test results. The $\mathrm{PPP}^{A}$, UIP and LIR long-run relations are valid for South Africa. The MD and GAP relations do not hold. Comparing South Africa's results to those from earlier VECX* studies (Table 1), the same long-run relations that hold for Indonesia are valid for South Africa. 
To confirm the valid relations and to determine the causality of the relationships, we also use the cointegrated VAR approach. This confirms that the $\mathrm{PPP}^{A}$, UIP and LIR long-run relationships are valid for South Africa. It further indicates that the direction of causality is in line with expectations, especially that domestic variables do not have an impact on foreign variables in the long term. It therefore verifies the assumption that the foreign variables are weakly exogenous.

The long-term equations from the ARDL method for the valid relations are included below, with the standard errors of the coefficients shown in brackets. The coefficients are all statistically significant. The real effective exchange rate is $e p$, calculated from the nominal effective exchange rate and domestic prices $(e p=e-p) . d 92$ is a dummy variable that is zero up to $1991 \mathrm{Q} 4$ and one from 1992 Q1 onwards.

$$
\begin{aligned}
& P P P^{A}: \quad e p_{t}=-0.754 p_{t}^{*}-1.779\left(y_{t}-y_{t}^{*}\right) \quad-0.349\left(d 92_{t}\right) \quad+\varepsilon_{t}^{1} \\
& \begin{array}{lll}
(0.029) \quad(0.840) \quad(0.131)
\end{array} \\
& \begin{array}{lrrr}
\text { UIP : } & r_{t}=0.018 & +0.649 r_{t}^{*} & +\varepsilon_{t}^{2} \\
& (0.004) & (0.219) & \\
\text { LIR : } & r_{t}=0.021 & +0.392 \pi_{t} & +\varepsilon_{t}^{3} \\
& (0.004) & (0.219) &
\end{array}
\end{aligned}
$$

In the UIP the coefficient of $r^{*}$ is not significantly different from one, but in the LIR the coefficient of $\pi$ is significantly different from one, suggesting that the modified Fisher parity may be more relevant. It should be taken into account that all the models tested are single-equation models. The VECX* will account for further interactions.

To summarise, the data results indicate three potential long-term economic relations for the country. The next section shows that the VECX* cointegration test results do suggest three cointegrating relations.

\section{VECX* model results}

We chose the variables to include in the VECX* model based on the results of the preliminary data analysis. The domestic endogenous variables included in the VECX* model are real output $(y)$, the quarterly inflation rate $(\pi)$, the repo rate $(r)$, the long-term interest rate $(l r)$ and the real effective exchange rate (calculated as $e p=e-p$, from the nominal effective exchange rate and prices). The weakly exogenous variables are foreign real output $\left(y^{*}\right)$, foreign prices $\left(p^{*}\right)$, the foreign short-term interest rate $\left(r^{*}\right)$ and the oil price $\left(p^{\text {oil }}\right)$. Interest rates are adjusted to be comparable with the quarterly inflation rate. All the variables are used in natural logarithmic form.

The VECX* model for South Africa was developed in Microfit 5.0 (Pesaran \& Pesaran, 2009a; 2009b). The Akaike information criterion (AIC) indicates that the optimal model has two lags of the endogenous variables and one lag of the exogenous variables. Table 3 contains the cointegration test results for the model with an unrestricted intercept, a restricted trend, a restricted dummy variable $(d 92)$ and an unrestricted differenced dummy variable $(D(d 92))$. 
The marginal models for the weakly exogenous foreign variables each include one lag for the differenced endogenous variables, one lag for the differenced exogenous variables and an intercept. In Table 3, the maximum eigenvalue statistic suggests a rank of three at a 10 per cent level of significance, while the trace statistic indicates a rank of three at a 5 per cent level of significance. Thus, there are three cointegrating relationships in the model, which is in line with the three significant long-run economic relations identified in Section 5.

These relations are the augmented purchasing power parity $\left(\mathrm{PPP}^{A}\right)$, the uncovered interest parity (UIP) and the modified Fisher parity (LIR). The restrictions of these relations are imposed on the VECX* to identify the model. The first cointegrating vector relates to $\mathrm{PPP}^{A}$, which can be written as $e p+$ $p^{*}-\beta_{1}\left(y-y^{*}\right)$. The restrictions are: $\pi=0, r=0, l r=0, e p=1, p^{*}=1$, $r^{*}=0, p^{\text {oil }}=0$, trend $=0$ and $d 92=0$. In the second cointegrating vector, relating to UIP or $r-r^{*}$, the following variables are restricted: $y=0, \pi=0$, $r=1, l r=0, e p=0, y^{*}=0, p^{*}=0, r^{*}=-1, p^{\text {oil }}=0$, trend $=0$ and $d 92=0$. The third cointegrating vector, relating to LIR or $r-\beta_{2} \pi$, makes the following restrictions: $y=0, r=-1, l r=0, e p=0, y^{*}=0, p^{*}=0, r^{*}=0, p^{\text {oil }}=0$, trend $=0$ and $d 92=0$.

The estimates ${ }^{4}$ of the overidentified cointegrating vectors are shown below, with the standard errors of the estimated coefficients shown in brackets. The intercepts of the three equations are $b_{10}, b_{20}$ and $b_{30}$ respectively, while the error correction terms are $\xi_{1 t}, \xi_{2 t}$ and $\xi_{3 t}$.

$$
\begin{aligned}
& P P P^{A}: \quad e p_{t}=-p_{t}^{*}-2.534\left(y_{t}-y_{t}^{*}\right)+b_{10}+\xi_{1 t} \\
& \text { UIP }: \quad r_{t}=r_{t}^{*}+b_{20}+\xi_{2 t} \\
& \text { LIR : } \quad r_{t}=0.781 \pi_{t}+b_{30}+\xi_{3 t}
\end{aligned}
$$

The log-likelihood ratio (LR) test, which has a $\chi^{2}(22)$ distribution, marginally rejects the 22 overidentifying restrictions. The LR test statistic of 85.53 is above the 99 per cent bootstrapped critical value of 80.83 (based on 3000 simulations). Since the LR test often over-rejects the null hypothesis that the restrictions are valid (Pesaran \& Pesaran, 2009b), we decide to use the model with the overidentifying restrictions given the strong theoretical foundations of the three long-run relations. Overall the $\mathrm{VECX}^{*}$ performs well according to the reduced-form error correction equations, the diagnostics statistics, the persistence profiles and the generalised impulse response functions. This would not have been the case if the long-run cointegrating restrictions were invalid.

Table 4 shows the reduced-form error correction equations and the diagnostics statistics of the $\mathrm{VECX}^{*}$. The lagged error corrections terms from the long-run relations, also known as deviations, are significant in several equations. Deviations from the $\mathrm{PPP}^{A}$ explain inflation and the real effective exchange rates. The deviation of the domestic repo rate from the foreign short-run interest rate is significant in the output, inflation, repo rate and long-run interest rate differ-

\footnotetext{
${ }^{4}$ These estimates are in line with those of the Indonesian model (Affandi, 2007), where the same restrictions were imposed.
} 
ential equations. A deviation from LIR explains changes in inflation.

At a 5 per cent level of significance, the diagnostic test results indicate that the residuals do not have normal distributions in most of the equations. At a 10 per cent level of significance, there is also some serial correlation in the equations for inflation and the real effective exchange rate, while there is misspecification in the interest rate equation.

The persistence profiles (PPs) of the three cointegrating vectors (Figure 10) converge to zero, indicating that the model will return to its long-run equilibrium following shocks to the system ${ }^{5}$.

The generalised impulse response functions (GIRFs) are generally in line with expectations. Appendix B contains all the GIRFs for the VECX*. The GIRFs (Figures 13 and 16 respectively in Appendix B) indicate that a positive shock to the official interest rate results in a decline in real output and an appreciation in the real effective exchange rate. Output is one of the intermediate targets of monetary policy. The movements are in line with our a priori expectations, except that output does not start to recover after 12 months. The effect of a monetary policy shock on inflation (the ultimate target of monetary policy) is in line with our a priori expectations.

The effect of a shock to the monetary policy interest rate (repo rate) on the inflation rate, as illustrated in Figure 11, suggests a monetary policy lag of around 24 months (8 quarters). A "prize puzzle" is only observed in the first quarter following the monetary policy shock. Thereafter, the inflation rate declines as anticipated in response to the interest rate increase. The same movements with monetary policy lags of about eight quarters are evident in the relevant impulse response functions of the models for Switzerland (AssenmacherWesche \& Pesaran, 2009), Thailand (Akusuwan, 2005) and Indonesia (Affandi, 2007).

The VECX* model therefore shows the expected transmission of monetary policy in South Africa between 1979 and 2009, with results in line with those of VECX* models for other countries.

\section{Conclusion and future research}

We develop a new type of model for South Africa to investigate the "timing and effect" (Mishkin, 1995) of a monetary policy change on inflation. The model includes foreign variables calculated from time-varying trade-weighted data for 32 countries, due to substantial changes in South Africa's main trading partners. This is also a first for South Africa, since previous models use the US as a proxy for the rest of the world or they use trade-weighted data for a fixed period to represent the rest of the world. Three statistically significant long-run economic

\footnotetext{
${ }^{5}$ We compared the PPs of this model with those of the Indonesian model (Affandi, 2007). The $\mathrm{PP}$ of $\mathrm{PPP}^{A}$ for South Africa is more stable with smaller confidence intervals than the one for Indonesia. The PPs of UIP and LIR for Indonesia return to their long-run equilibrium at a faster pace than the PPs for South Africa, but the PP of UIP for Indonesia shows an impact on the cointegrating vector after a system-wide shock that is twice the size of that for the PP of UIP for South Africa.
} 
relations identify the model. These are the purchasing power parity (PPP), the uncovered interest parity (UIP) and the Fisher parity (LIR). The lag between a change in the repo rate and the full impact on inflation is around 24 months. The VECX* model thus shows the effective transmission of monetary policy in South Africa between 1979 and 2009.

For future research, we want to determine whether and how global economic shocks affect the transmission of monetary policy in South Africa. Bain and Howells (2003) mention that many factors influence the time lags involved in the monetary transmission mechanism, including "the state of business and consumer confidence, how this confidence is influenced by monetary policy changes, events in the world economy and expectations about future inflation". If global economic shocks do have an effect on the domestic monetary transmission mechanism, then policy makers would need to consider this in the aftermath of international crises.

To study this, we will incorporate the South African VECX* model in a customised GVAR model for South Africa, where all the foreign variables are endogenously determined from individual $\mathrm{VECX}^{*}$ models for the main trading partners. We will utilise the theoretical framework introduced and expanded by Pesaran et al. (2004), Garratt et al. (2006), Dees, Di Mauro, Pesaran and Smith (2007), Pesaran, Schuermann and Smith (2009a) and Pesaran, Schuermann and Smith (2009b). The aim is to determine the impact of economic shocks in the rest of the world on the South African economy.

\section{References}

[1] Affandi, Y. 2007. A small monetary system for Indonesia: A long run structural approach. PhD thesis. Cambridge: Faculty of Economics, University of Cambridge.

[2] Akusuwan, M. 2005. A small quarterly macroeconometric model for the Thai economy: A structural cointegrating VAR approach. $\mathrm{PhD}$ thesis. Cambridge: Faculty of Economics, University of Cambridge.

[3] Assenmacher-Wesche, K. \& Pesaran, M.H. 2008. Forecasting the Swiss economy using VECX* models: An exercise in forecast combination across models and observation windows. National Institute Economic Review, 203(January): 91-108.

[4] Assenmacher-Wesche, K. \& Pesaran, M.H. 2009. A VECX* model of the Swiss economy. Swiss National Bank Economic Studies, no. 6.

[5] Bain, K. \& Howells, P. 2003. Monetary economics: Policy and its theoretical application. Hampshire: Palgrave Macmillan.

[6] Bank of England. 1999. The transmission mechanism of monetary policy. [Online] Available from: http:/?/?www.bankofengland.co.uk/ ?publications/?other/?monetary/?montrans.pdf [Accessed: 2006-07-27]. 
[7] Casteleijn, A.J.H. 2001. South Africa's monetary policy framework. Paper presented at the Monetary Policy Frameworks in Africa Conference, South African Reserve Bank, Pretoria, 17-19 September.

[8] De Jager, S. 2007. A steady state QPM model for the South African economy. Pretoria: South African Reserve Bank, Working Paper 07/03.

[9] De Wet, A.H., Van Eyden, R. \& Gupta, R. 2009. Linking global economic dynamics to a South African-specific credit risk correlation model. Economic Modelling , 26: 1000-1011.

[10] Dees, S., Di Mauro, F., Pesaran, M.H. \& Smith, L.V. 2007. Exploring the international linkages of the euro area: A global VAR analysis. Journal of Applied Econometrics, 22: 1-38.

[11] Garratt, A., Lee, K., Pesaran, M.H. \& Shin, Y. 2003. A long run structural macroeconometric model of the UK. Economic Journal, 113(487): 412-455.

[12] Garratt, A., Lee, K., Pesaran, M.H. \& Shin, Y. 2006. Global and national macroeconometric modelling: A long-run structural approach. Oxford: Oxford University Press.

[13] Gordhan, P. 2010. Clarification of the Reserve Bank's mandate. Pretoria: South African Reserve Bank. [Online] Available from: http://www.reservebank.co.za/internet/Publication.nsf/WhatsNew/E647 B2BE34B12C14422576CE0044EA71?opendocument [Downloaded: 201002-18].

[14] Gupta, R. \& Steinbach, R. 2010. Forecasting key macroeconomic variables of the South African economy: A Small Open Economy New Keynesian DSGE-VAR model. Pretoria: South African Reserve Bank, Discussion Paper $10 / 11$.

[15] Hendry, D.F. \& Richard, J.F. 1983. The econometric analysis of economic time series. International Statistical Review, 51(2): 111-148.

[16] International Monetary Fund. 2011. Direction of Trade Statistics. University of Manchester: ESDS International.

[17] Mishkin, F.S. 1995. Symposium on the monetary transmission mechanism. Journal of Economic Perspectives, 9(4): 3-10.

[18] Mishkin, F.S. 2004. The economics of money, banking and financial markets. Seventh edition. Boston: Pearson Addison-Wesley.

[19] Pesaran, B. \& Pesaran, M.H. 2009a. Microfit 5.0. Oxford: Oxford University Press.

[20] Pesaran, B. \& Pesaran, M.H. 2009b. Time series econometrics using Microfit 5.0. Oxford: Oxford University Press. 
[21] Pesaran, M.H., Schuermann, T. \& Smith, L.V. 2009a. Forecasting economic and financial variables with Global VARs. International Journal of Forecasting, 25: 642-675.

[22] Pesaran, M.H., Schuermann, T. \& Smith, L.V. 2009b. Rejoinder to comments on forecasting economic and financial variables with Global VARs. International Journal of Forecasting, 25: 703-715.

[23] Pesaran, M.H., Schuermann, T. \& Weiner, S. 2004. Modelling regional interdependencies using a global error-correcting macroeconometric model. Journal of Business and Economic Statistics, 22(2): 129-162.

[24] Pesaran, M.H. \& Shin, Y. 1999. An autoregressive distributed-lag modelling approach to cointegration (Chapter 11). In S. Strøm (ed.), Econometrics and economic theory in the 20th century: The Ragnar Frisch centennial symposium. Cambridge: Cambridge University Press.

[25] Pesaran, M.H. \& Shin, Y. 2002. Long-run structural modelling. Econometric Reviews, 21(1): 49-87.

[26] Pesaran, M.H., Shin, Y. \& Smith, R. J. 2000. Structural analysis of vector error correction models with exogenous $I(1)$ variables. Journal of Econometrics, 97(2): 293-343.

[27] Pesaran, M.H., Shin, Y. \& Smith, R. J. 2001. Bounds testing approaches to the analysis of level relationships. Journal of Applied Econometrics, 16: 289-326.

[28] Pesaran, M.H. \& Smith, R. 2006. Macroeconometric modelling with a global perspective. The Manchester School, 74(Supplement 1): 24-49.

[29] SARB. 2007. The core forecasting model of the South African Reserve Bank. Pretoria: South African Reserve Bank.

[30] Smal, M.M. \& De Jager, S. 2001. The monetary transmission mechanism in South Africa. Pretoria: South African Reserve Bank, Occasional Paper 16 .

[31] Smith, L.V. \& Galesi, A. 2011. GVAR Toolbox 1.1. [Online] Available from: http://www.cfap.jbs.cam.ac.uk/research/gvartoolbox [Downloaded: 2011-08-09].

[32] Steinbach, R., Mathuloe, P. \& Smit, B. 2009. An open economy New Keynesian DSGE model of the South African economy. Pretoria: South African Reserve Bank, Working Paper 09/01. 
Table 1: Long-term economic relationships in previous VECX* studies

\begin{tabular}{cccc}
\hline & Switzerland & Thailand & Indonesia \\
\hline PPP $^{\mathrm{a}}$ & $\checkmark$ & $\boldsymbol{x}$ & $\checkmark$ \\
$\mathbf{U I P}^{\mathrm{b}}$ & $\checkmark$ & $\checkmark$ & $\checkmark$ \\
$\mathbf{L I R}^{\mathrm{c}}$ & $\checkmark$ & $\checkmark$ & $\checkmark$ \\
$\mathbf{M D}^{\mathrm{d}}$ & $\checkmark$ & $\checkmark$ & $\boldsymbol{x}$ \\
$\mathbf{G A P}^{\mathrm{e}}$ & $\checkmark$ & $\boldsymbol{x}$ & $\boldsymbol{x}$ \\
\hline
\end{tabular}

${ }^{a}$ PPP: Purchasing power parity $\left(p-p^{*}-e\right)$ or $\mathrm{PPP}^{\mathrm{A}}$ : Augmented purchasing power parity $\left(e-\left(p-p^{*}\right)-\beta_{1}\left(y-y^{*}\right)\right)$

b UIP: Uncovered interest parity $\left(r-r^{*}\right)$

${ }^{\mathrm{c}}$ LIR: Fisher parity $(r-\pi)$ or Modified Fisher parity $\left(r-\beta_{2} \pi\right)$

${ }^{\mathrm{d}} \mathrm{MD}$ : Money demand relationship $\left(m-\beta_{3} y-\beta_{4} r\right)$

${ }^{\mathrm{e}}$ GAP: Relation between domestic output and foreign output $\left(y-y^{*}\right)$

Table 2: Long-term economic relationships: ARDL cointegration test results

\begin{tabular}{lcccccccc}
\hline & EC $^{\mathrm{a}}$ & $\boldsymbol{t}_{\text {-stat }}{ }^{\mathrm{b}}$ & \multicolumn{2}{c}{ CV bounds } & $\boldsymbol{F}^{\mathrm{c}}$-stat $^{\mathrm{b}}$ & \multicolumn{2}{c}{ CV bounds $^{\mathrm{c}}$} & ${\text { ARDL }(\boldsymbol{p}, \boldsymbol{q}, \boldsymbol{s})^{\mathrm{d}}}^{\mathrm{e}}$ \\
\hline PPP $^{\mathbf{A}}$ & -0.16 & $-3.39^{*}$ & -2.57 & -3.21 & $-3.91^{*}$ & $2.89^{\mathrm{e}}$ & $3.86^{\mathrm{e}}$ & ARDL $(4,0,1)$ \\
UIP & -0.12 & $-4.11^{*}$ & -2.57 & -2.91 & $8.01^{*}$ & 4.04 & 4.78 & ARDL $(2,0)$ \\
LIR & -0.10 & $-3.54^{*}$ & -2.57 & -2.91 & $5.42^{*}$ & 4.04 & 4.78 & ARDL $(2,0)$ \\
MD & -0.08 & -2.94 & -2.57 & -3.21 & 3.81 & 3.17 & 4.14 & ARDL $(2,4,0)$ \\
GAP & -0.02 & -1.19 & -3.13 & -3.40 & 2.24 & 5.59 & 6.26 & ARDL $(2,2)$ \\
\hline
\end{tabular}

${ }^{a}$ Error correction term.

b Significant $t$-stat or F-stat indicated by * (10\% level of significance).

${ }^{c}$ Lower and upper 90\% critical value bounds (Pesaran, Shin \& Smith, 2001).

${ }^{\mathrm{d}}$ Lag lengths selected by the Akaike information criterion (AIC), with maximum four lags. The models include an intercept, except for $\mathrm{PPP}^{\mathrm{A}}$ that includes a dummy variable from 1992 onwards and GAP that includes an intercept and a trend.

${ }^{\mathrm{e}}$ Lower and upper 90\% critical value bounds from Microfit 5.0 (Pesaran \& Pesaran, 2009a). These critical values are simulated stochastically to be valid in the presence of the dummy variable in $\mathrm{PPP}^{\mathrm{A}}$.

Table 3: Cointegration test results

\begin{tabular}{ccccc}
\hline \multicolumn{5}{c}{ Maximum Eigenvalue } \\
\hline Null & Alternative & Statistic & $95 \%$ critical value & $90 \%$ critical value \\
\hline $\mathrm{r}=0$ & $\mathrm{r}=1$ & $\mathbf{6 5 . 7 6}$ & 52.34 & 49.18 \\
$\mathrm{r} \leq 1$ & $\mathrm{r}=2$ & $\mathbf{5 8 . 4 9}$ & 45.42 & 41.89 \\
$\mathrm{r} \leq 2$ & $\mathrm{r}=\mathbf{3}$ & $\mathbf{3 6 . 8 3}$ & 37.79 & 34.81 \\
$\mathrm{r} \leq 3$ & $\mathrm{r}=4$ & $\mathbf{1 9 . 4 5}$ & 30.05 & 27.44 \\
$\mathrm{r} \leq 4$ & $\mathrm{r}=5$ & $\mathbf{1 7 . 3 9}$ & 21.78 & 19.06 \\
\hline \multicolumn{5}{c}{ Trace } \\
\hline Null & Alternative & Statistic & $95 \%$ critical value & $90 \%$ critical value \\
\hline $\mathrm{r}=0$ & $\mathrm{r} \geq 1$ & $\mathbf{1 9 7 . 9 2}$ & 135.94 & 130.02 \\
$\mathrm{r} \leq 1$ & $\mathrm{r} \geq 2$ & $\mathbf{1 3 2 . 1 6}$ & 100.48 & 95.03 \\
$\mathrm{r} \leq 2$ & $\mathrm{r} \geq \mathbf{3}$ & $\mathbf{7 3 . 6 7}$ & 68.97 & 64.71 \\
$\mathrm{r} \leq 3$ & $\mathrm{r} \geq 4$ & $\mathbf{3 6 . 8 4}$ & 43.34 & 40.08 \\
$\mathrm{r} \leq 4$ & $\mathrm{r}=5$ & $\mathbf{1 7 . 3 9}$ & 21.78 & 19.06 \\
\hline
\end{tabular}

The critical values (CVs) are simulated using 3000 replications. The CVs for two exogenous variables are considered, since there are two cointegrating relationships between the four exogenous variables. 
Table 4: Reduced-form error correction equations

\begin{tabular}{|c|c|c|c|c|c|}
\hline Equation & $\Delta y_{t}$ & $\Delta \pi_{t}$ & $\Delta r_{t}$ & $\Delta e p_{t}$ & $\Delta / r_{t}$ \\
\hline$\xi_{1, t-1}$ & -0.011 & $0.016^{*}$ & -0.002 & $-0.077^{*}$ & -0.001 \\
\hline$\xi_{2, t-1}$ & $-0.274^{*}$ & $-1.060 *$ & $-0.124^{*}$ & 0.360 & $-0.073^{*}$ \\
\hline$\xi_{3, t-1}$ & 0.002 & $0.959 *$ & -0.035 & -0.205 & -0.028 \\
\hline$\Delta y_{t-1}$ & $0.468^{*}$ & 0.063 & $0.066^{*}$ & 0.141 & -0.009 \\
\hline$\Delta \pi_{t-1}$ & 0.019 & 0.031 & $0.044^{*}$ & 0.128 & $0.037 *$ \\
\hline$\Delta r_{t-1}$ & 0.102 & 0.402 & $0.036^{*}$ & 2.217 & 0.092 \\
\hline$\Delta e p_{t-1}$ & -0.010 & 0.016 & 0.000 & 0.124 & 0.002 \\
\hline$\Delta l r_{t-1}$ & 0.441 & 0.645 & 0.001 & -4.594 & 0.095 \\
\hline$\Delta y^{*}$ & 0.180 & 0.112 & -0.013 & 1.445 & 0.034 \\
\hline$\Delta p^{*}{ }_{t}$ & -0.209 & $-0.575^{*}$ & -0.031 & 0.559 & -0.009 \\
\hline$\Delta r_{t}^{*}$ & -0.004 & $0.624 *$ & 0.148 & -0.825 & -0.102 \\
\hline$\Delta p_{t}^{o i l}$ & $0.010^{*}$ & $0.011^{*}$ & 0.001 & -0.059 & $0.002 *$ \\
\hline Intercept & $0.018^{*}$ & -0.008 & 0.002 & 0.038 & 0.002 \\
\hline$\Delta d 92$ & -0.008 & -0.004 & -0.002 & -0.077 & -0.001 \\
\hline Adjusted $\mathrm{R}^{2}$ & 0.420 & 0.404 & 0.300 & 0.096 & 0.118 \\
\hline Serial correlation: $\chi^{2}(4)$ & 4.696 & $8.761^{*}$ & 1.361 & $8.523^{*}$ & 3.053 \\
\hline Functional form: $\chi^{2}(1)$ & 0.357 & 0.296 & $3.287^{*}$ & 0.220 & 0.959 \\
\hline Normality: $\chi^{2}(2)$ & $62.699 *$ & 1.137 & $237.57^{*}$ & $18.771^{*}$ & $35.252^{*}$ \\
\hline Heteroscedasticity: $\chi^{2}(1)$ & 0.006 & 0.010 & 0.006 & 0.300 & 0.034 \\
\hline
\end{tabular}

An asterisk denotes significance at the 10\% level. 
Figure 1: Three-year moving average trade weights $(\%)$ for 15 main trading partners $(1980$ - 2009) China
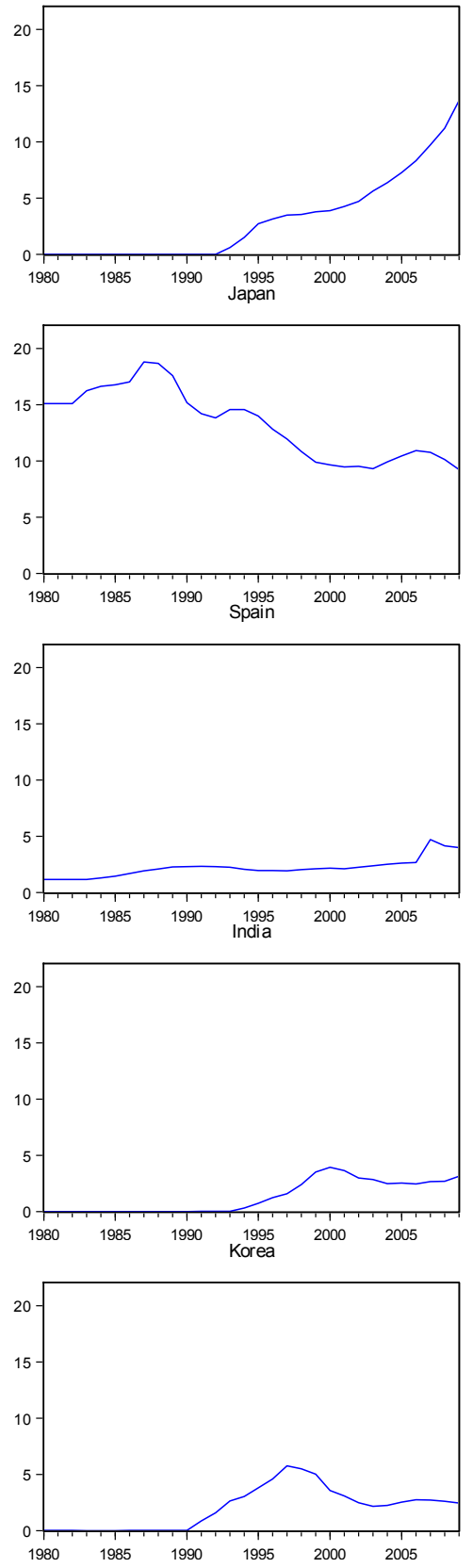

Germany
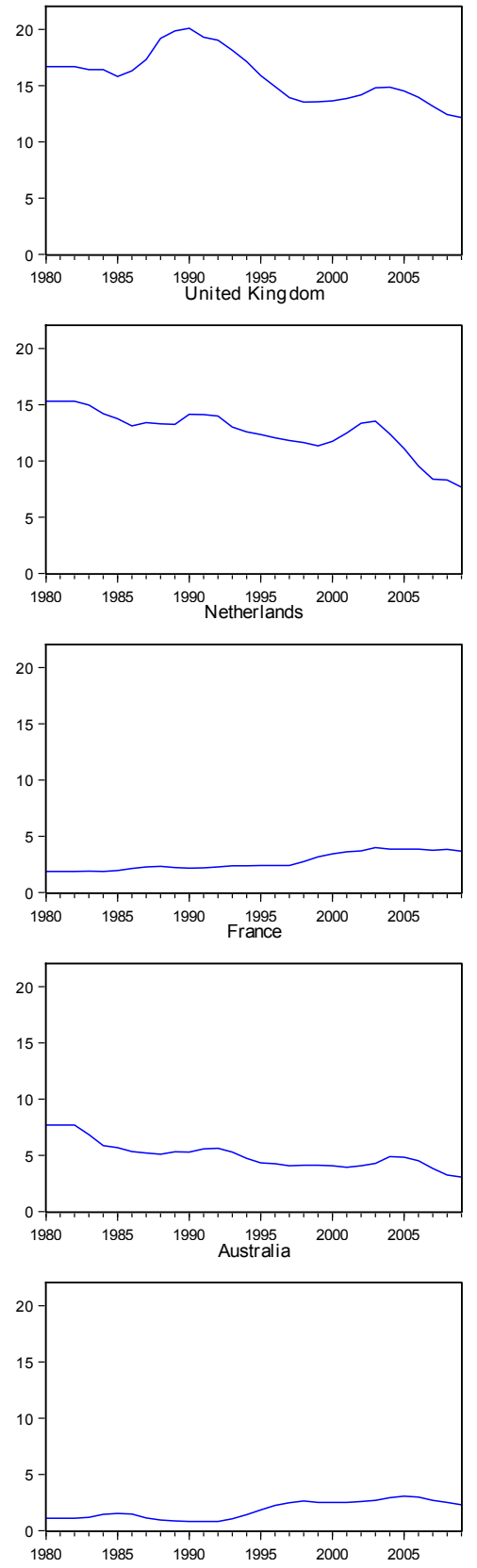

United States
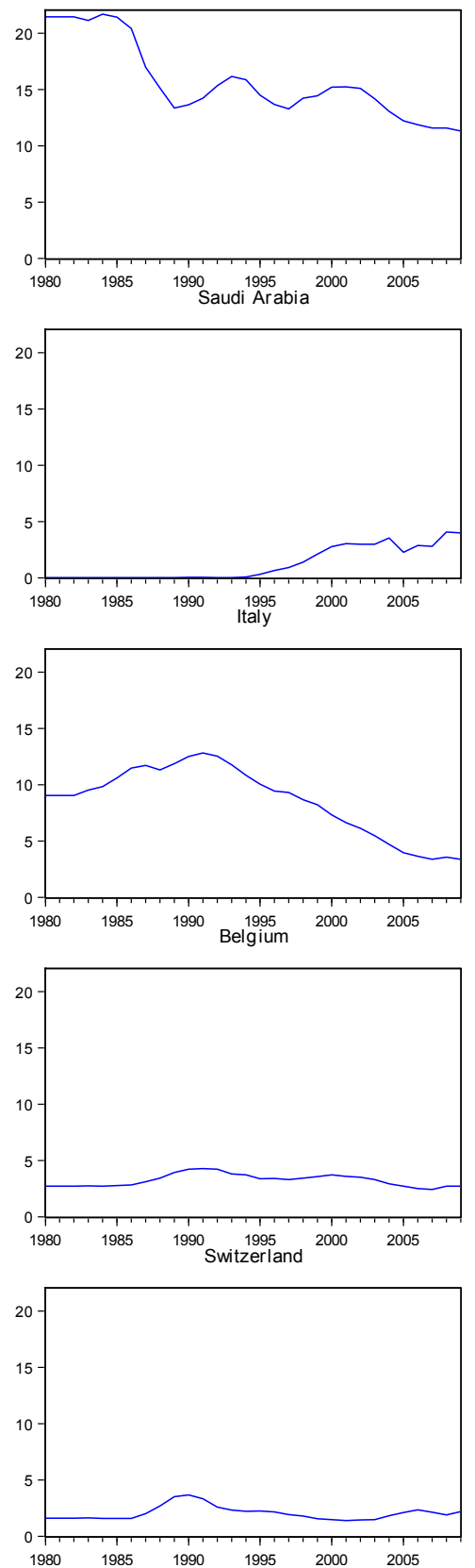

Figure 2: Three-year moving average trade weight (\%) for Euro area (1980 - 2009)

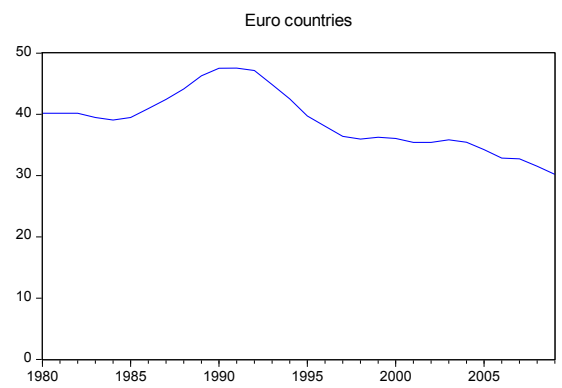


Figure 3: Exchange rate and ratio of domestic to foreign prices
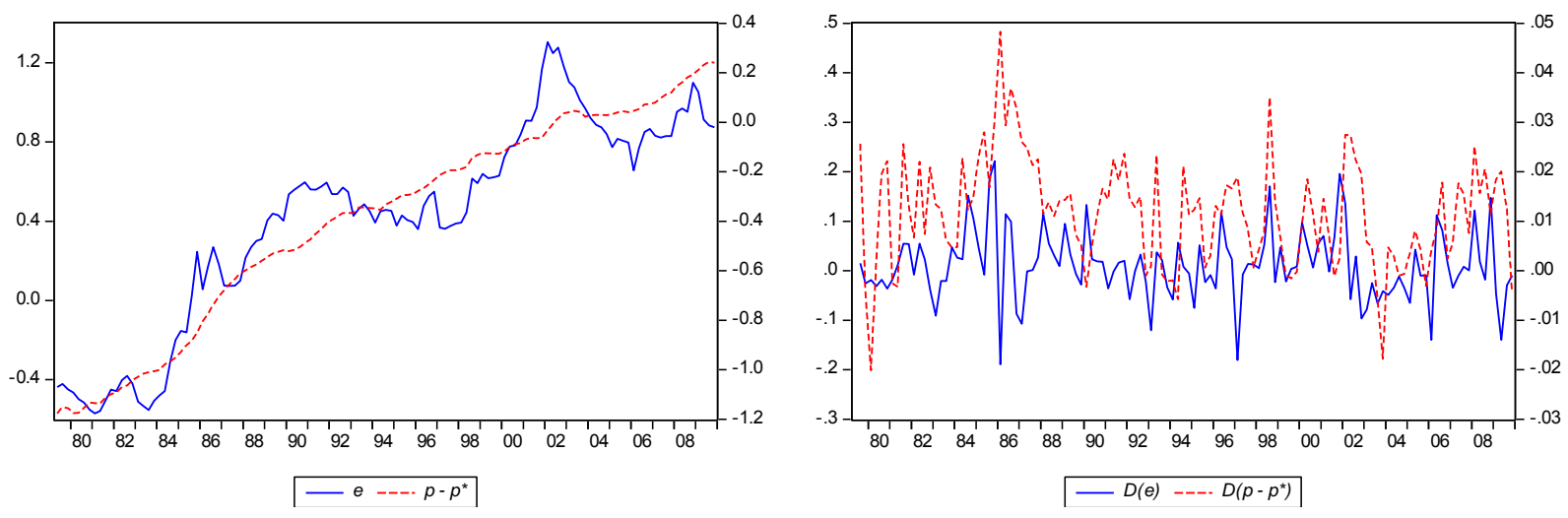

Figure 4: Exchange rate and ratio of domestic to foreign output
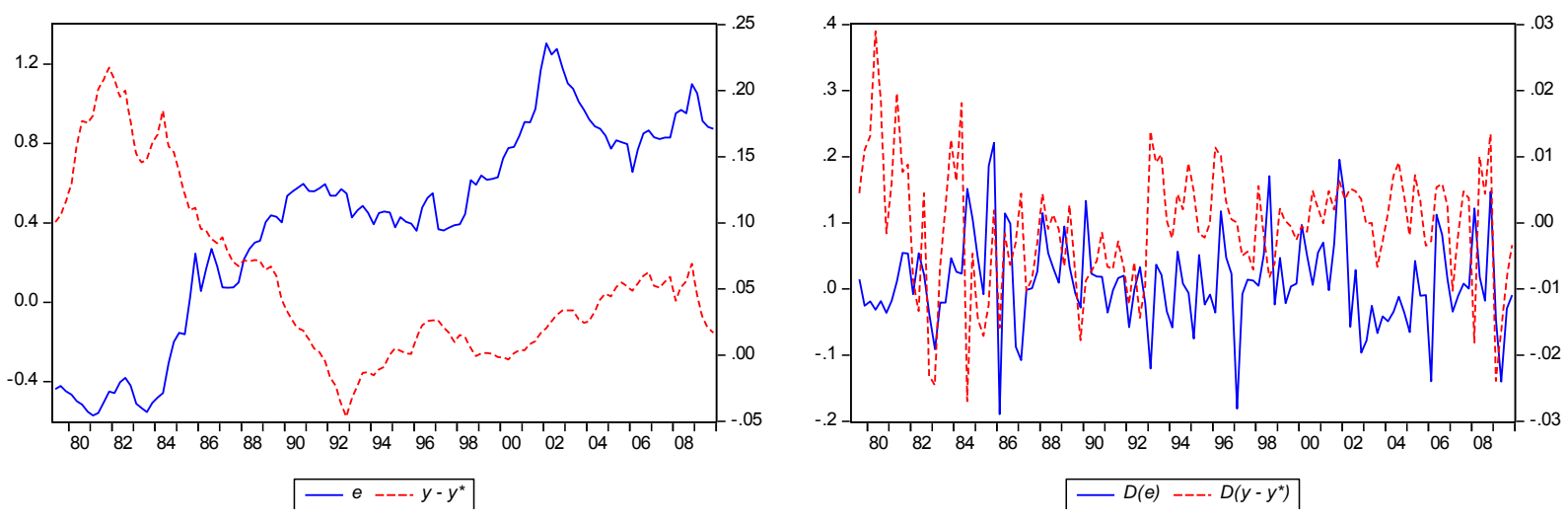

Figure 5: Domestic and foreign short-term interest rates
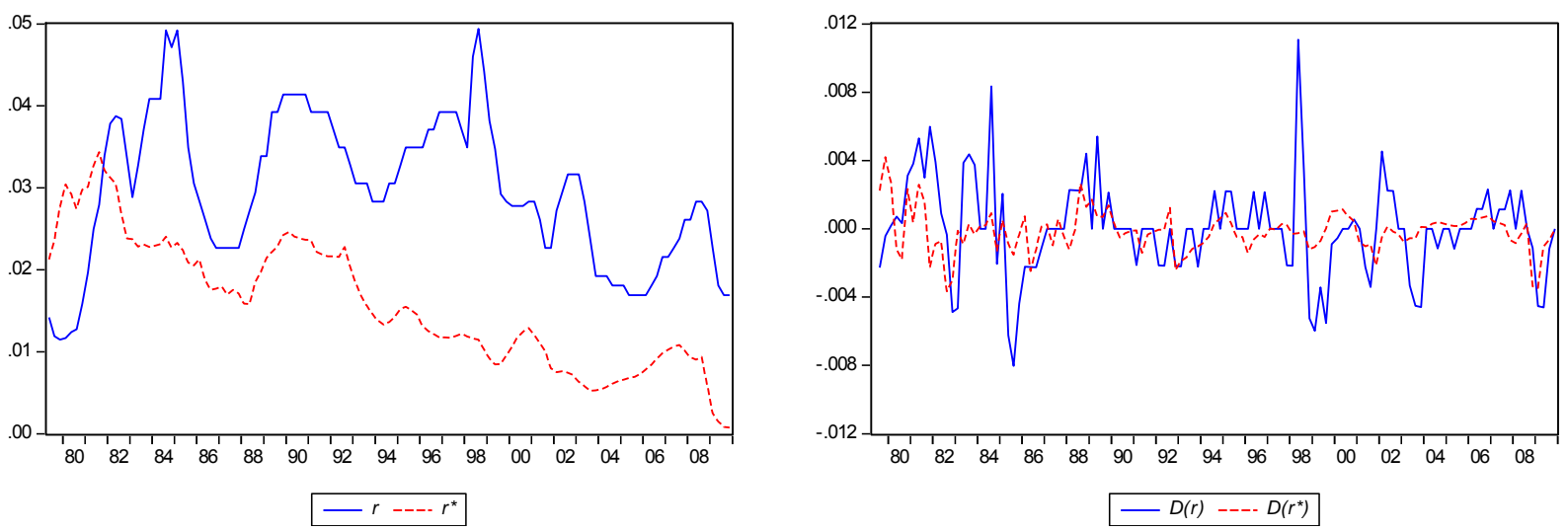
Figure 6: Short-term interest rates and inflation
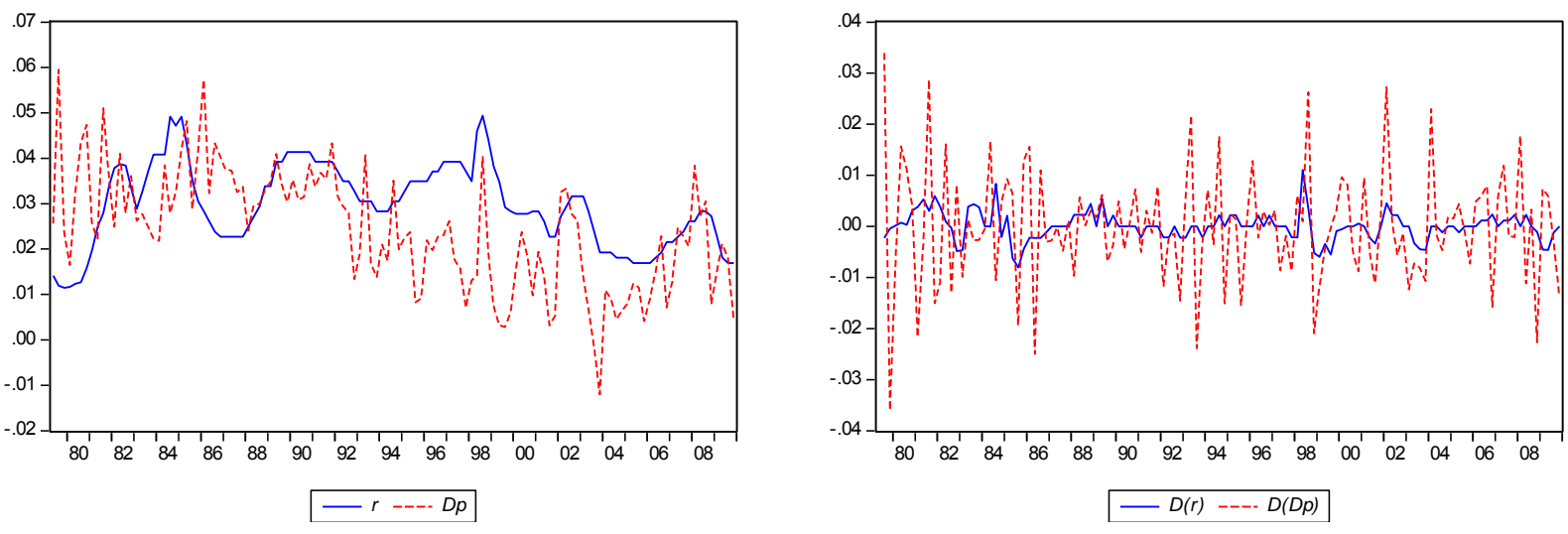

Figure 7: Broad money (M3) and output
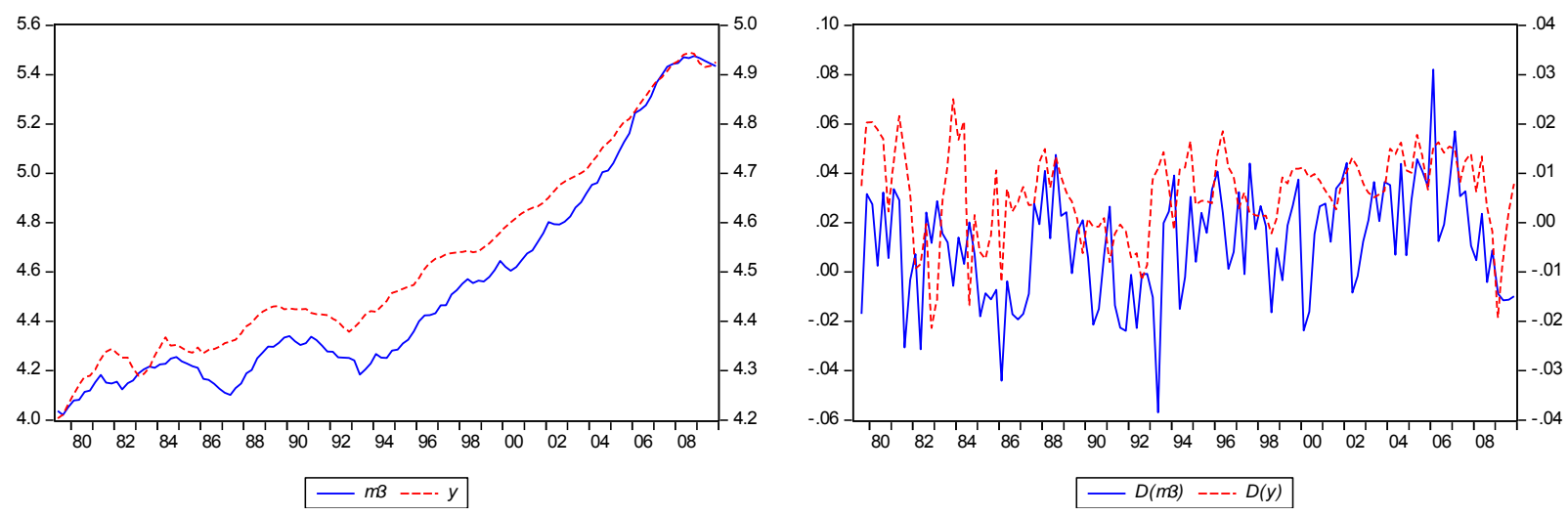

Figure 8: M3 and short-term interest rates
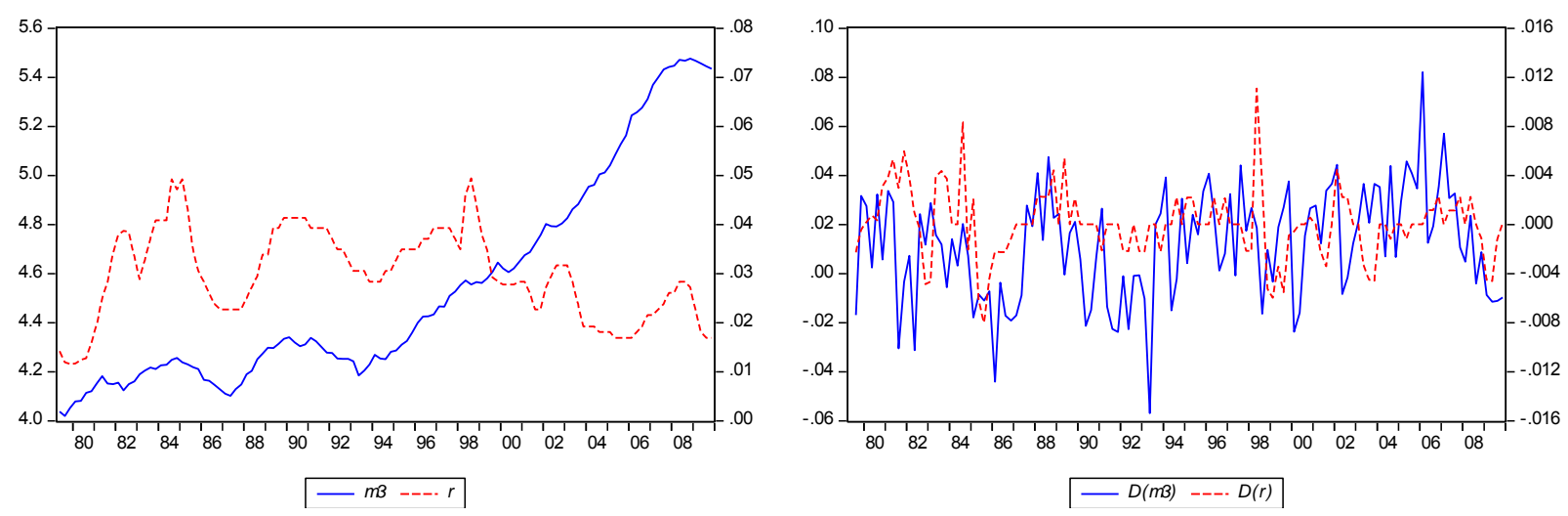
Figure 9: Domestic and foreign output
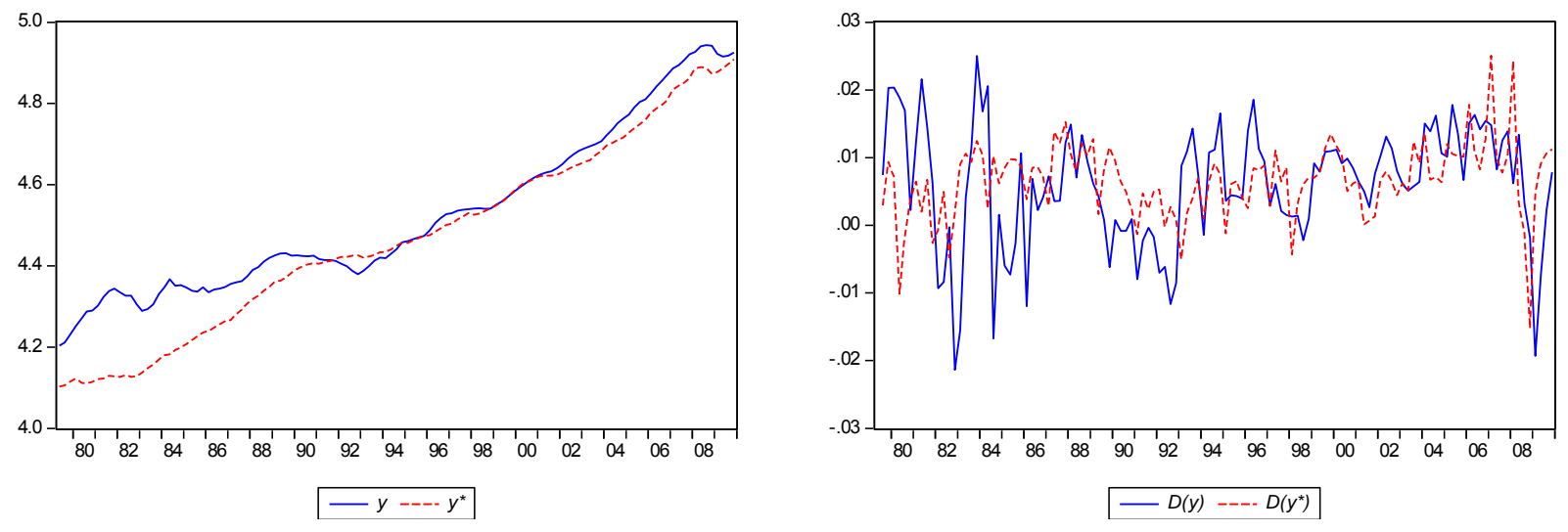

Figure 10: Persistence profiles of the effect of a system-wide shock to the cointegrating vectors with $95 \%$ bootstrapped confidence intervals

Augmented PPP

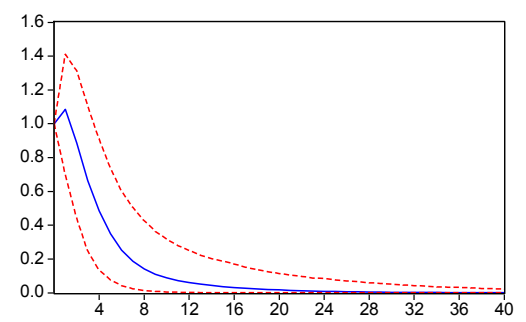

UIP

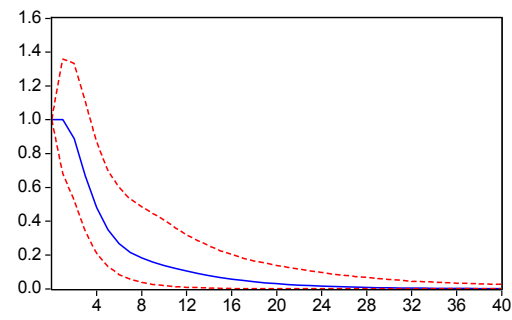

LIR

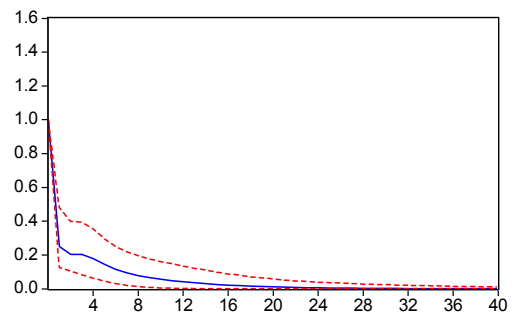

Figure 11: Generalised impulse response for inflation to a one standard error shock to the repo rate with $95 \%$ bootstrapped confidence intervals

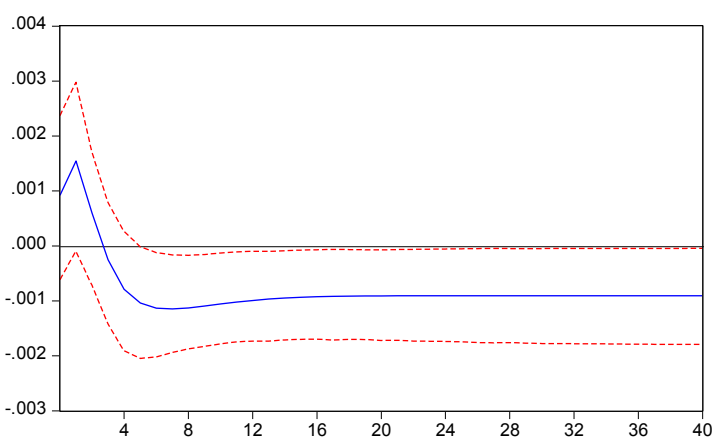




\section{Appendix A: Data}

Except for broad money supply (M3) for South Africa, the data are from the GVAR Toolbox 1.1 dataset (Smith \& Galesi, 2011), which includes data for 33 countries accounting for around 90 per cent of world output. Comprehensive information about the data sources and the methods of calculation for the GVAR Toolbox 1.1 database is included in Technical Appendix B of the User Guide compiled by Smith and Galesi (2011). M3 for South Africa is from the International Financial Statistics (IFS) of the International Monetary Fund (IMF).

For the creation of the foreign variables, the three-year moving average trade weights of South Africa with each of the other 32 counties in the GVAR dataset were calculated from the annual trade data (average of exports and imports, c.i.f. ${ }^{1}$ ) between 1980 and 2009. We used the time-varying trade shares to weigh each variable for all the countries. The summation of the weighted country data provided the specific foreign variable.

The 32 countries in the GVAR are responsible for 77 per cent of South Africa's average trade from 2006 to 2010 with the rest of the world, according to more recent data from the Direction of Trade Statistics (DOTS) of the IMF (2011). Table 5 shows the individual and total trade shares based on this data.

Table 5: Average trade shares of countries included in the model (2006 - 2010)

\begin{tabular}{lc}
\hline Country & Average trade share \\
\hline China & $10.58 \%$ \\
\hline Germany & $9.78 \%$ \\
\hline USA & $8.82 \%$ \\
\hline Japan & $7.45 \%$ \\
\hline UK & $5.52 \%$ \\
\hline Saudi Arabia & $3.20 \%$ \\
\hline Netherlands & $2.90 \%$ \\
\hline India & $2.74 \%$ \\
\hline Spain & $2.55 \%$ \\
\hline Italy & $2.50 \%$ \\
\hline France & $2.48 \%$ \\
\hline Belgium & $1.91 \%$ \\
\hline Korea & $1.89 \%$ \\
\hline Australia & $1.82 \%$ \\
\hline Switzerland & $1.64 \%$ \\
\hline Brazil & $1.43 \%$ \\
\hline Thailand & $1.39 \%$ \\
\hline Malaysia & $1.09 \%$ \\
\hline Sweden & $1.08 \%$ \\
\hline Singapore & $0.97 \%$ \\
\hline Argentina & $0.91 \%$ \\
\hline Canada & $0.81 \%$ \\
\hline Turkey & $0.68 \%$ \\
\hline Indonesia & $0.67 \%$ \\
\hline Austria & $0.57 \%$ \\
\hline Finland & $0.50 \%$ \\
\hline Mexico & $0.36 \%$ \\
\hline Norway & $0.24 \%$ \\
\hline New Zealand & $0.17 \%$ \\
\hline Philippines & $0.13 \%$ \\
& \\
\hline
\end{tabular}

\footnotetext{
${ }^{1}$ Cost, insurance and freight.
} 


\begin{tabular}{lc}
\hline Country & Average trade share \\
\hline Chile & $0.12 \%$ \\
Peru & $0.05 \%$ \\
\hline Total & $\mathbf{7 6 . 9 5 \%}$ \\
\hline Euro countries & $23.20 \%$ \\
\hline
\end{tabular}

Source: Calculated from DOTS of the IMF (Direction of Trade Statistics, 2011).

Table 6 lists the variables. Variables without an assigned type are not in the final VECX* model, but they are used for calculations and for analysis. Interest rates are adjusted to be comparable with the quarterly inflation rate. All the variables are used in natural logarithmic form. The foreign variables are calculated using the three-year moving average trade shares of the 32 trading partners to weigh the relevant foreign data. Unit root tests indicate that the variables in the model are $I(1)$.

\section{Table 6: Variables}

\begin{tabular}{|c|c|c|c|}
\hline Variable & Name & Description & Type \\
\hline$y$ & $\mathbf{Y}$ & In real GDP & Endogenous $I(1)$ \\
\hline$\pi$ & DP & Quarterly inflation rate: first difference of $\ln \mathrm{CPI}$ & Endogenous $I(1)$ \\
\hline$r$ & $\mathbf{R}$ & $0.25 * \ln (1+$ repo rate $/ 100)$ & Endogenous $I(1)$ \\
\hline$e$ & $\mathbf{E}$ & In nominal effective exchange rate & \\
\hline$p$ & $\mathbf{P}$ & $\ln \mathrm{CPI}$ & \\
\hline ep & EP & In real effective exchange rate $=\mathrm{e}-\mathrm{p}$ & Endogenous $I(1)$ \\
\hline Ir & $\mathbf{L R}$ & $0.25 * \ln (1+$ long-term interest rate $/ 100)$ & Endogenous $I(1)$ \\
\hline$m 3$ & M3 & In real M3 & \\
\hline$y^{*}$ & YS & In foreign real GDP & Exogenous $I(1)$ \\
\hline$p^{*}$ & PS & In foreign CPI & Exogenous $I(1)$ \\
\hline$r^{*}$ & RS & $0.25 * \ln (1+$ foreign short-term interest rate $/ 100))$ & Exogenous $I(1)$ \\
\hline$p^{o i l}$ & POIL & In oil price & Exogenous $I(1)$ \\
\hline$y-y^{*}$ & Y_YS & Ratio of $\ln$ real GDP to $\ln$ foreign real GDP & \\
\hline$p-p^{*}$ & P_PS & Ratio of $\ln$ CPI to $\ln$ foreign CPI & \\
\hline d92 & D92 & Dummy variable: 1 from 1992 Q1 onwards & Deterministic \\
\hline
\end{tabular}

Table 7: Simple correlation coefficients

\begin{tabular}{|c|c|c|c|c|c|c|c|c|c|c|c|c|c|c|}
\hline & $y$ & $\pi$ & $r$ & $e$ & $p$ & $e p$ & $L r$ & $m 3$ & $y^{*}$ & $p^{*}$ & $r^{*}$ & $p^{o i l}$ & $y-y^{*}$ & $p-p^{*}$ \\
\hline$y$ & 1 & & & & & & & & & & & & & \\
\hline$\pi$ & - & 1 & & & & & & & & & & & & \\
\hline$r$ & - & $0.24^{*}$ & 1 & & & & & & & & & & & \\
\hline$e$ & & $-0.48^{*}$ & -0.12 & 1 & & & & & & & & & & \\
\hline$p$ & 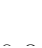 & $-0.61 *$ & -0.12 & $0.94^{*}$ & 1 & & & & & & & & & \\
\hline$e p$ & - & $0.66^{*}$ & 0.10 & $-0.70^{*}$ & $-0.91 *$ & 1 & & & & & & & & \\
\hline lr & - & $0.44^{*}$ & $0.72 *$ & $-0.29 *$ & $-0.37 *$ & $0.40^{*}$ & 1 & & & & & & & \\
\hline$m 3$ & & $-0.51 *$ & $-0.35^{*}$ & $0.73^{*}$ & $0.82 *$ & $-0.79 *$ & $-0.72 *$ & 1 & & & & & & \\
\hline$y^{*}$ & & $-0.58^{*}$ & $-0.26^{*}$ & $0.90^{*}$ & $0.97 *$ & $-0.88^{*}$ & $-0.54^{*}$ & $0.93 *$ & 1 & & & & & \\
\hline$p^{*}$ & & $-0.62 *$ & -0.08 & $0.92 *$ & $0.99 *$ & $-0.92^{*}$ & $-0.34 *$ & $0.80^{*}$ & $0.95^{*}$ & 1 & & & & \\
\hline$r^{*}$ & - & $0.64^{*}$ & $0.28 *$ & $-0.84^{*}$ & $-0.91 *$ & $0.84 *$ & $0.45^{*}$ & $-0.79 *$ & $-0.89 *$ & $-0.90 *$ & 1 & & & \\
\hline$p^{o i l}$ & 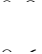 & -0.15 & $-0.49 *$ & 0.14 & $0.23^{*}$ & $-0.29 *$ & $-0.79 *$ & $0.69 *$ & $0.44^{*}$ & $0.21 *$ & $-0.21 *$ & 1 & & \\
\hline$y-y^{*}$ & - & $0.41 *$ & -0.06 & $-0.77 *$ & $-0.75^{*}$ & $0.60^{*}$ & -0.08 & $-0.31 *$ & $-0.62 *$ & $-0.76^{*}$ & $0.63^{*}$ & $0.28^{*}$ & 1 & \\
\hline$p-p^{*}$ & & $-0.60^{*}$ & $-0.16^{*}$ & $0.95^{*}$ & $0.99 *$ & $-0.89^{*}$ & $-0.40^{*}$ & $0.83^{*}$ & $0.97 *$ & $0.99 *$ & $-0.92 *$ & $0.25 *$ & $-0.75^{*}$ & 1 \\
\hline
\end{tabular}

An asterisk denotes significance at the $10 \%$ level. 
Figure 12 presents graphs of all the variables, while Table 7 contains the simple correlation coefficients between the variables.

Figure 12: Graphs of variables

Y

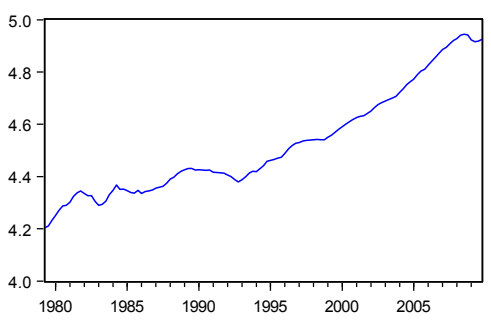

E

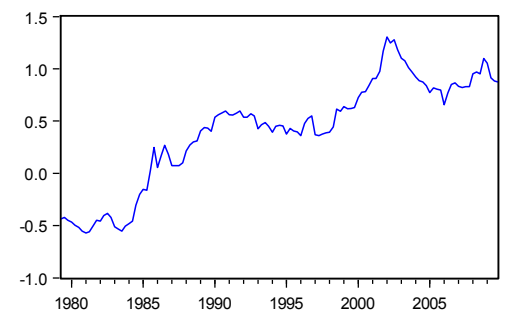

$\mathrm{LR}$

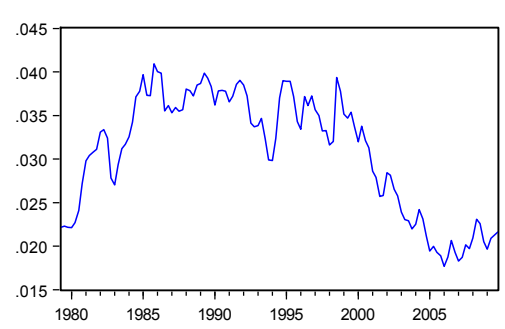

PS
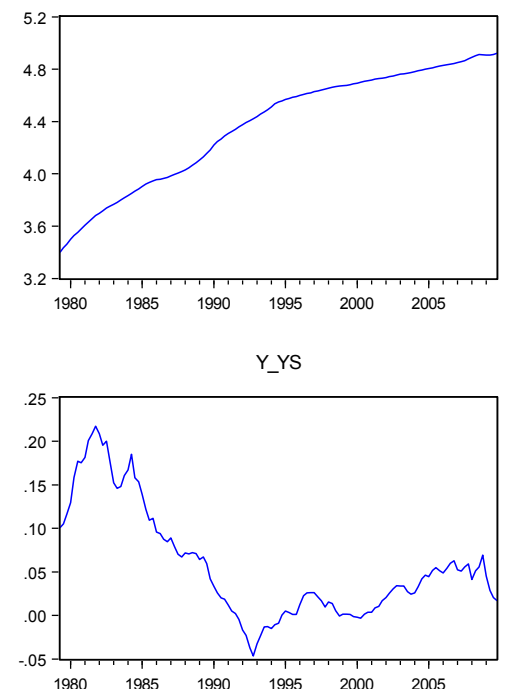

DP

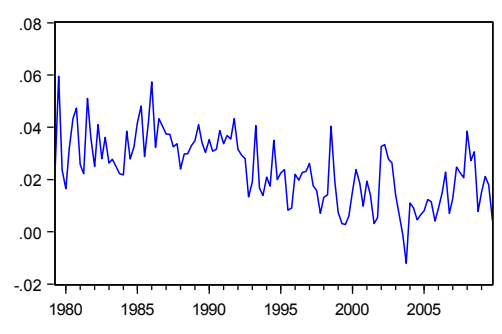

P

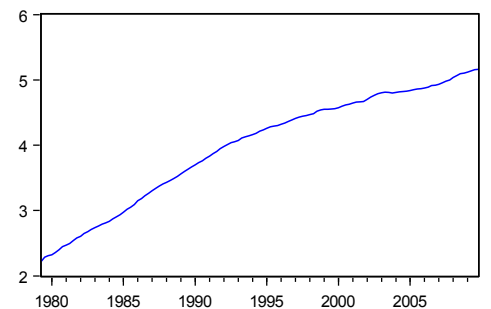

M3

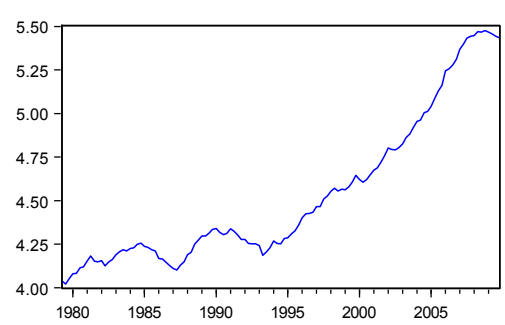

RS
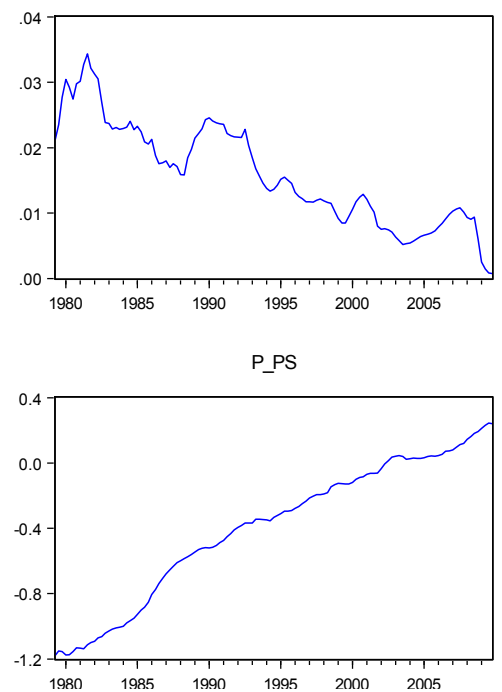

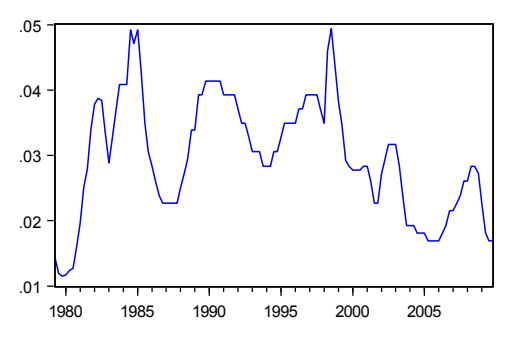

EP

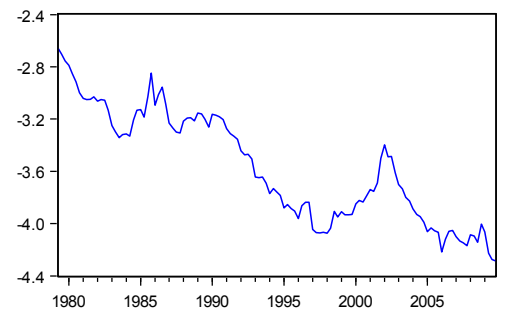

YS

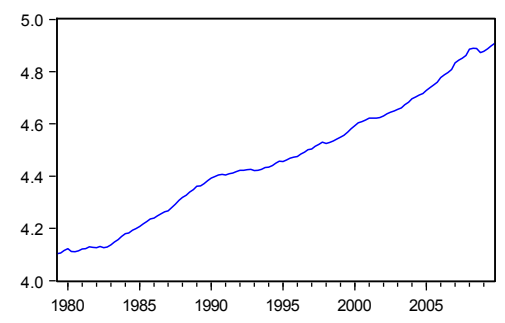

POIL

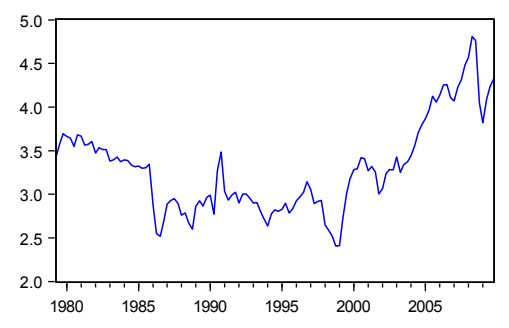




\section{Appendix B: GIRFs}

Figure 13: Generalised impulse responses for output with $95 \%$ bootstrapped confidence intervals
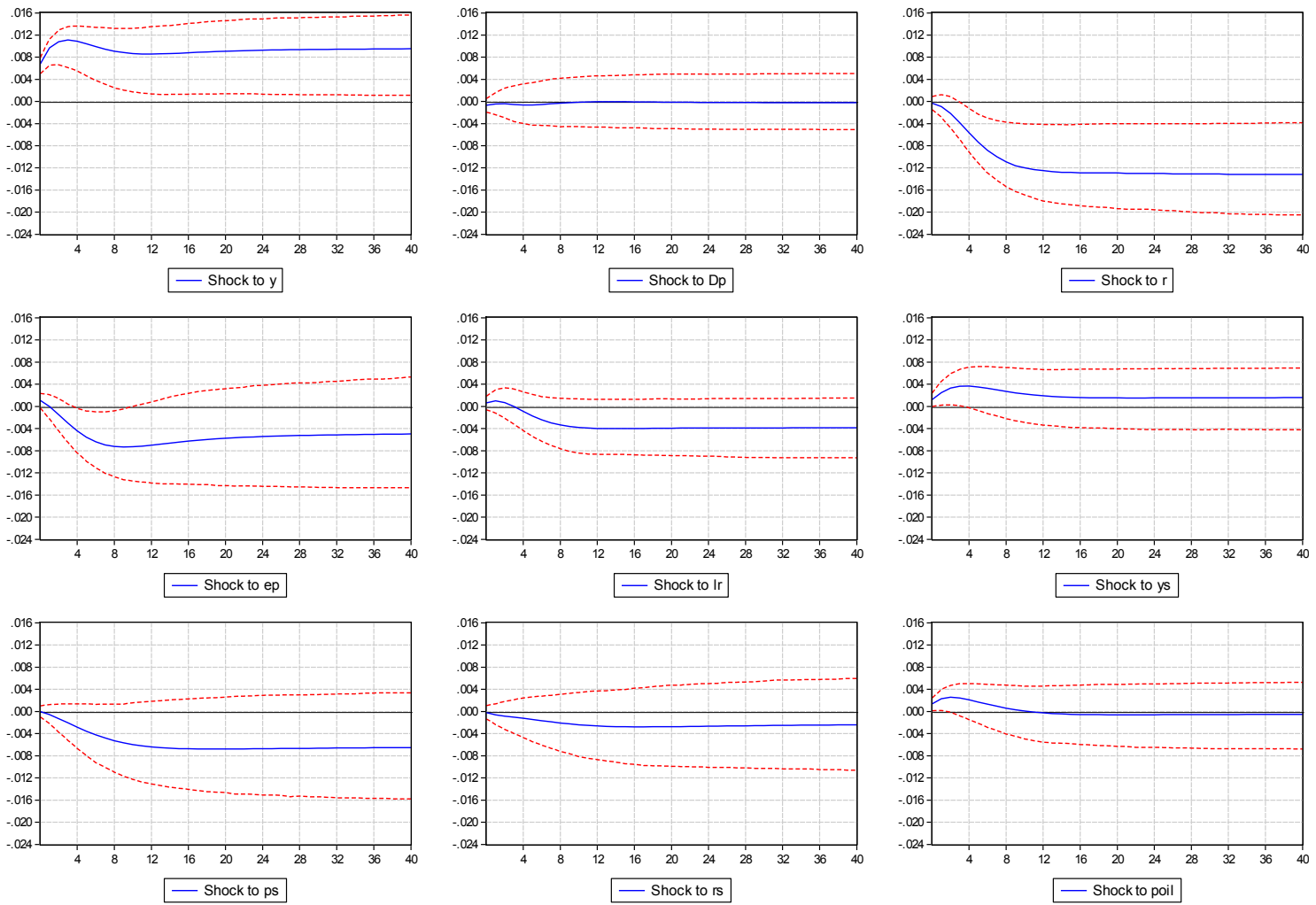

Figure 14: Generalised impulse responses for inflation with $95 \%$ bootstrapped confidence intervals
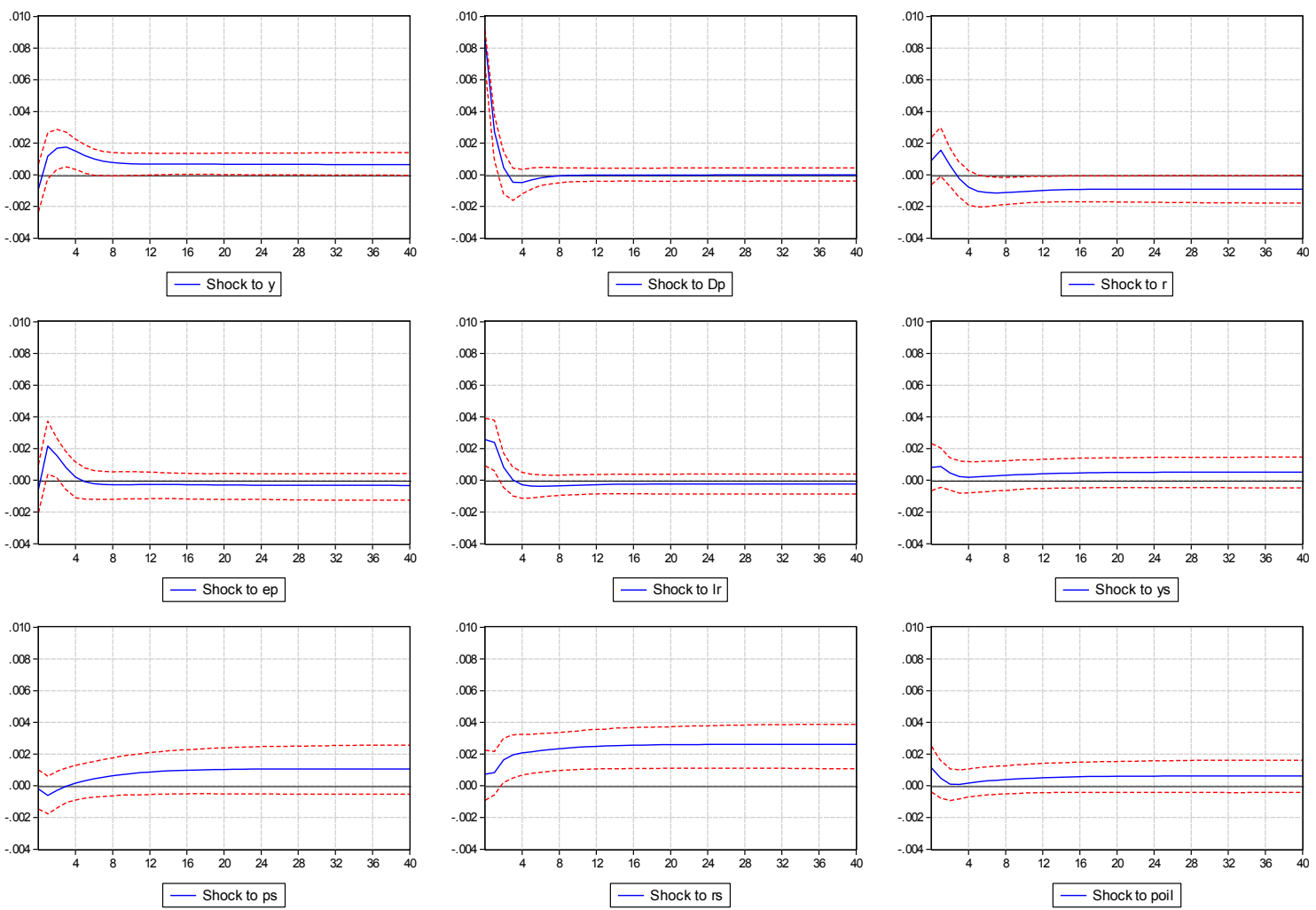
Figure 15: Generalised impulse responses for repo rate with $95 \%$ bootstrapped confidence intervals
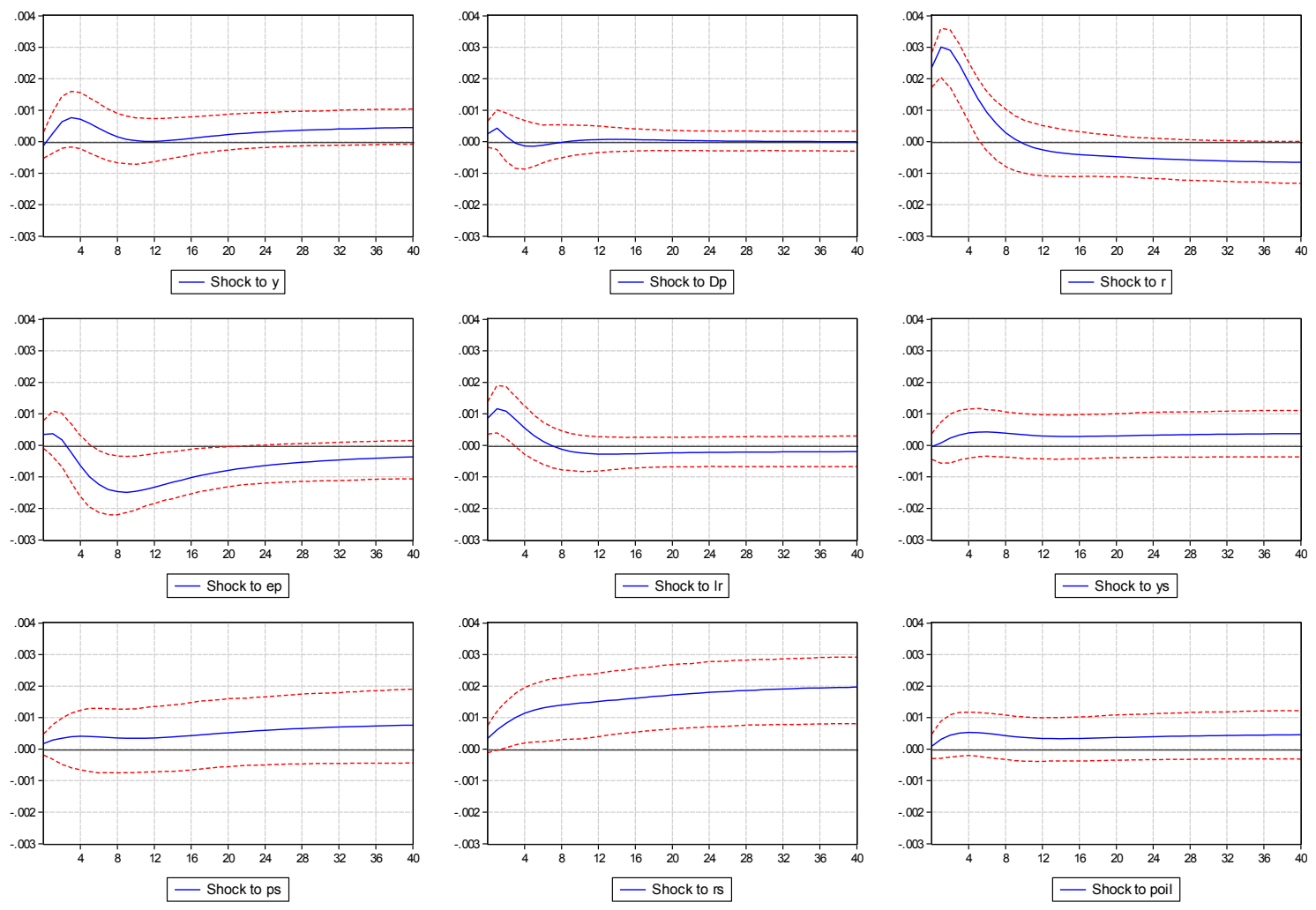

Figure 16: Generalised impulse responses for real effective exchange rate with $95 \%$ bootstrapped confidence intervals
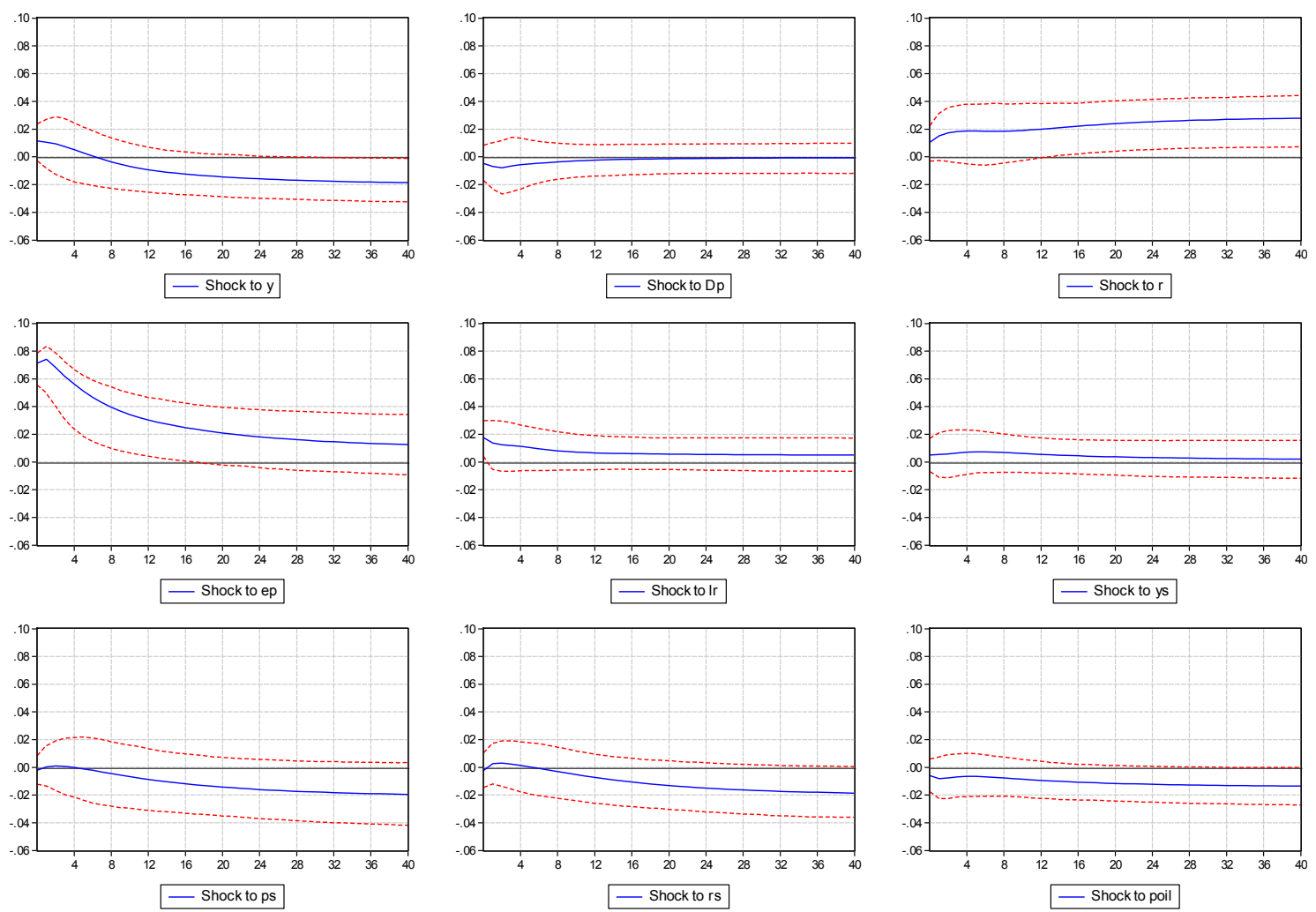
Figure 17: Generalised impulse responses for long-run interest rate with 95\% bootstrapped confidence intervals
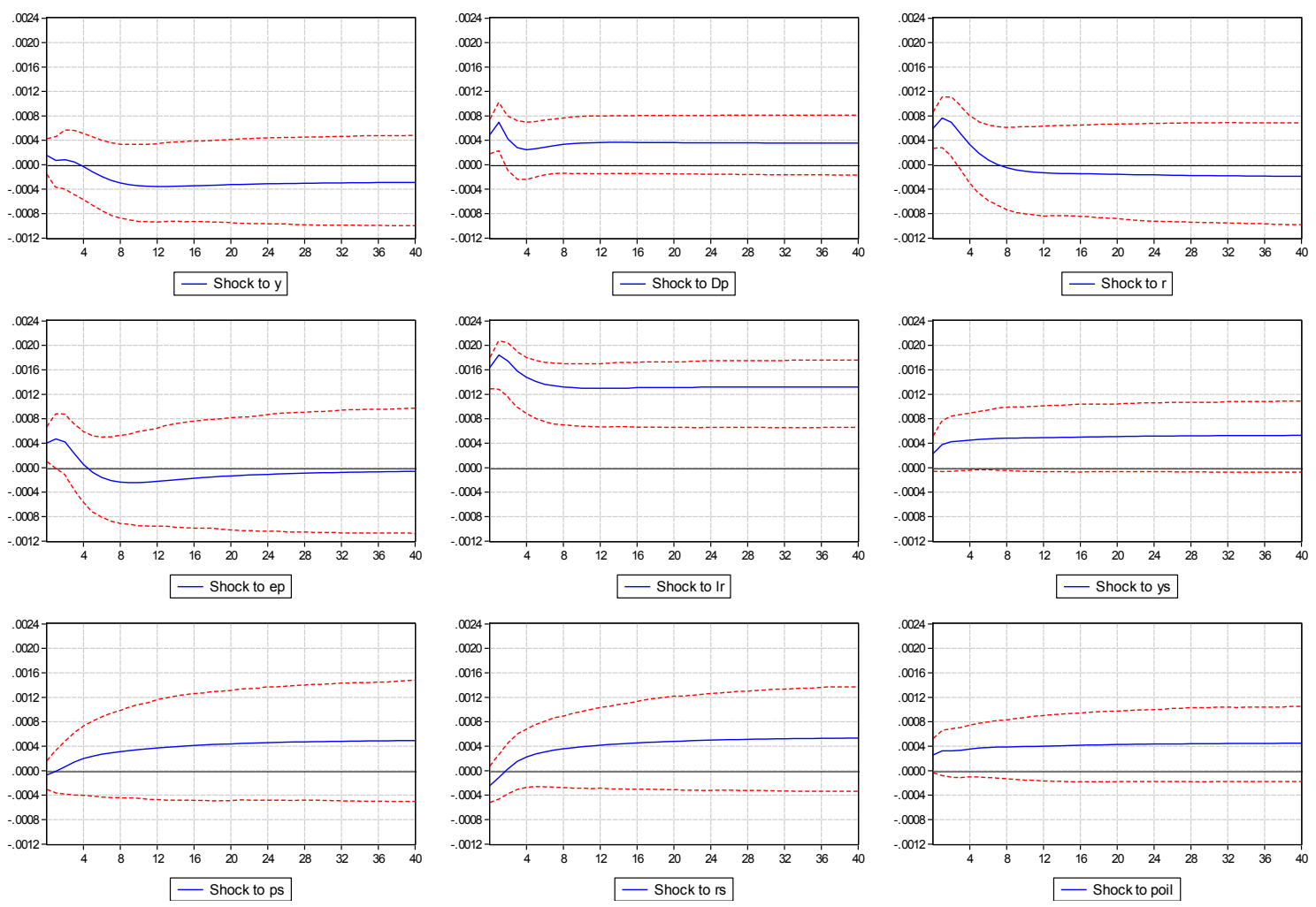

Figure 18: Generalised impulse responses for foreign output with $95 \%$ bootstrapped confidence intervals
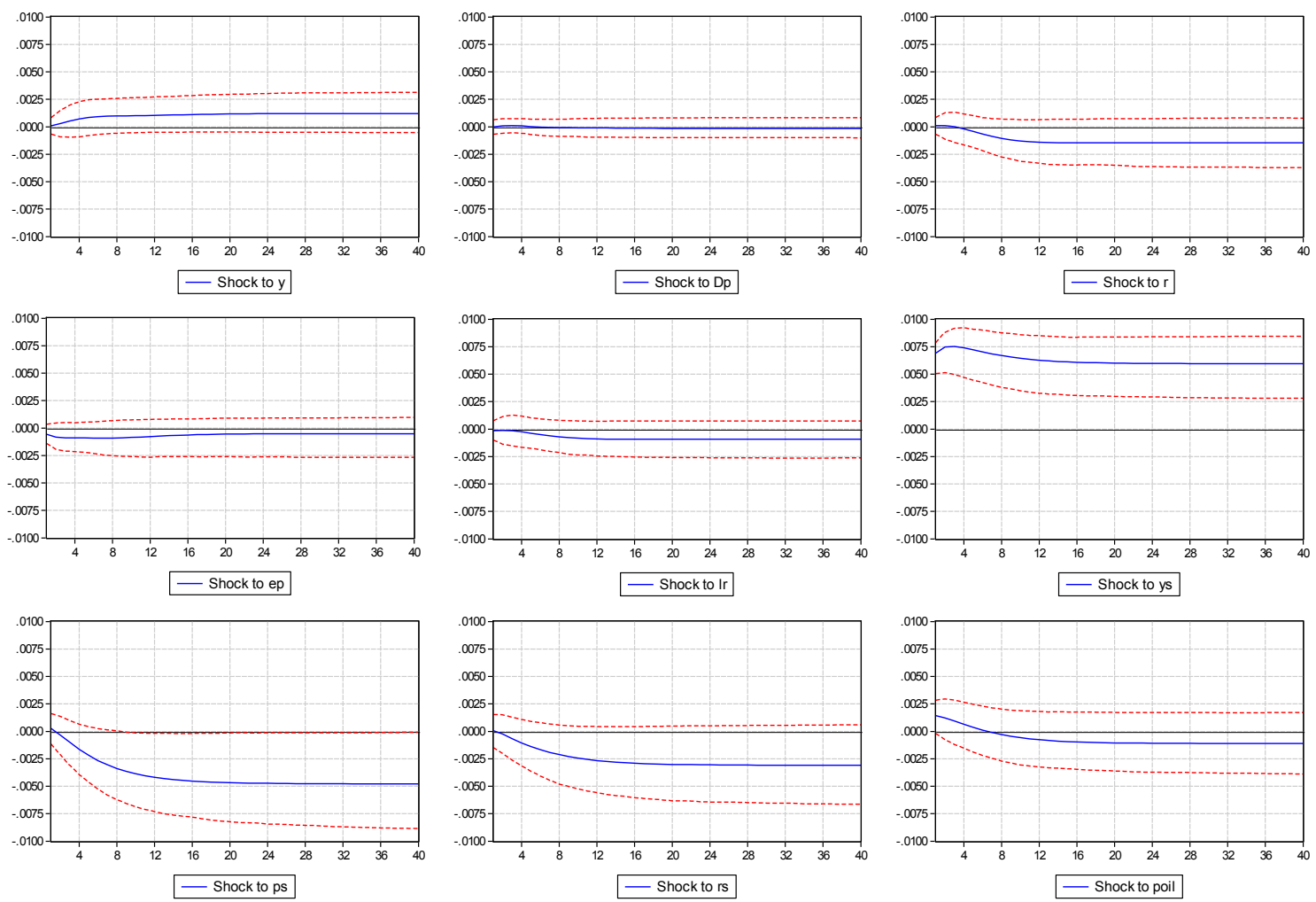
Figure 19: Generalised impulse responses for foreign prices with $95 \%$ bootstrapped confidence intervals
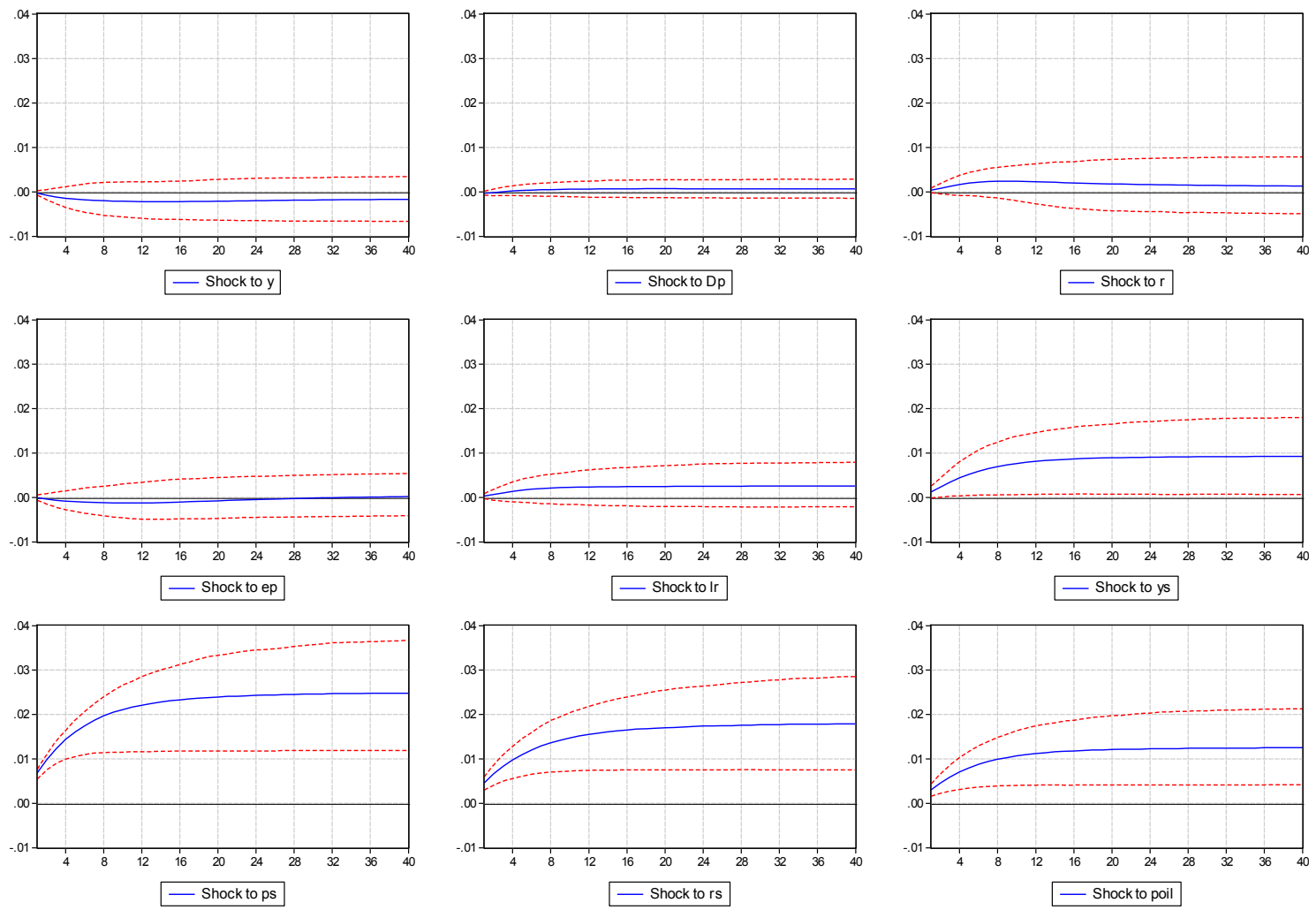

Figure 20: Generalised impulse responses for foreign short-term interest rates with $\mathbf{9 5 \%}$ bootstrapped confidence intervals
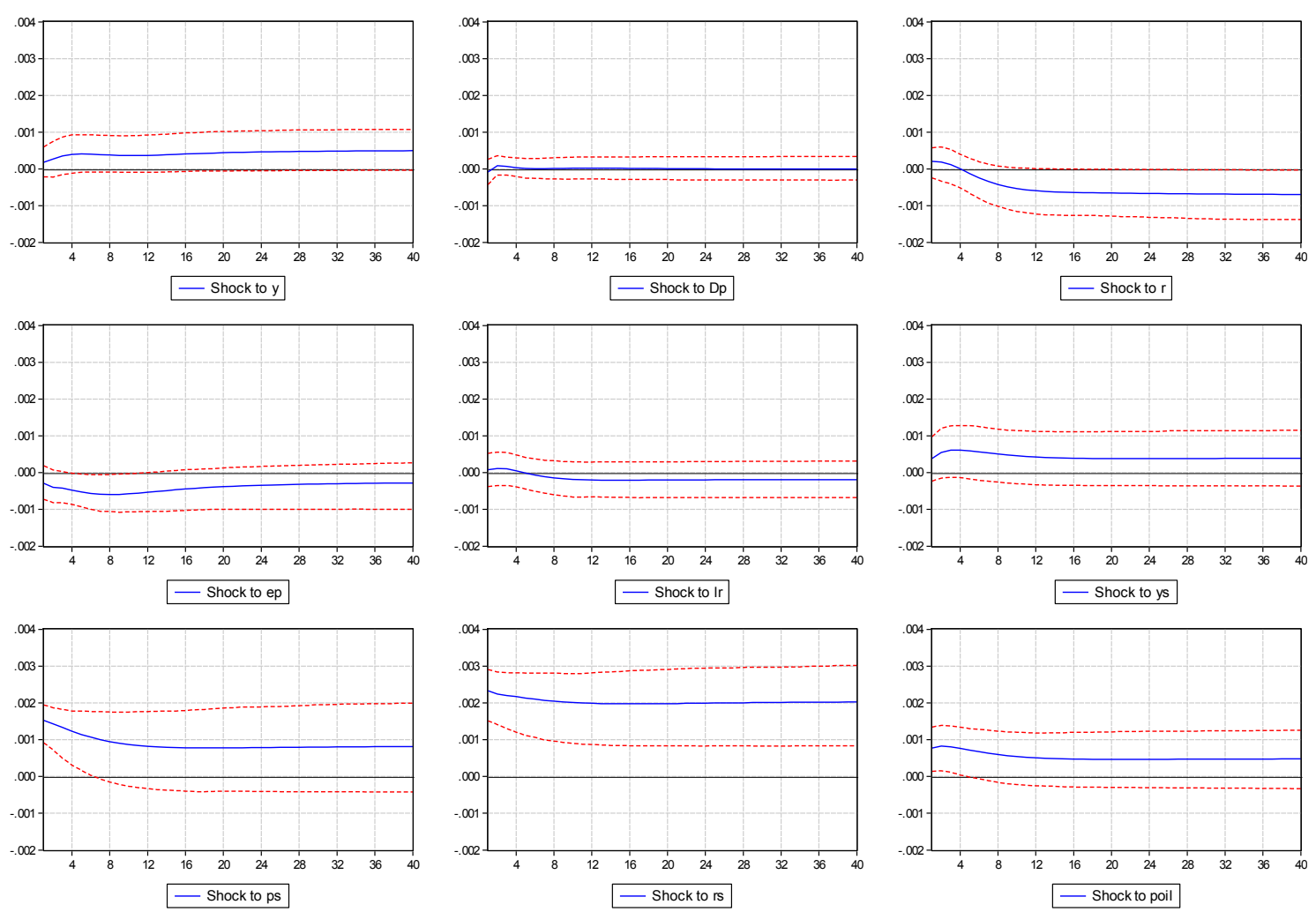
Figure 21: Generalised impulse responses for oil price with $95 \%$ bootstrapped confidence intervals
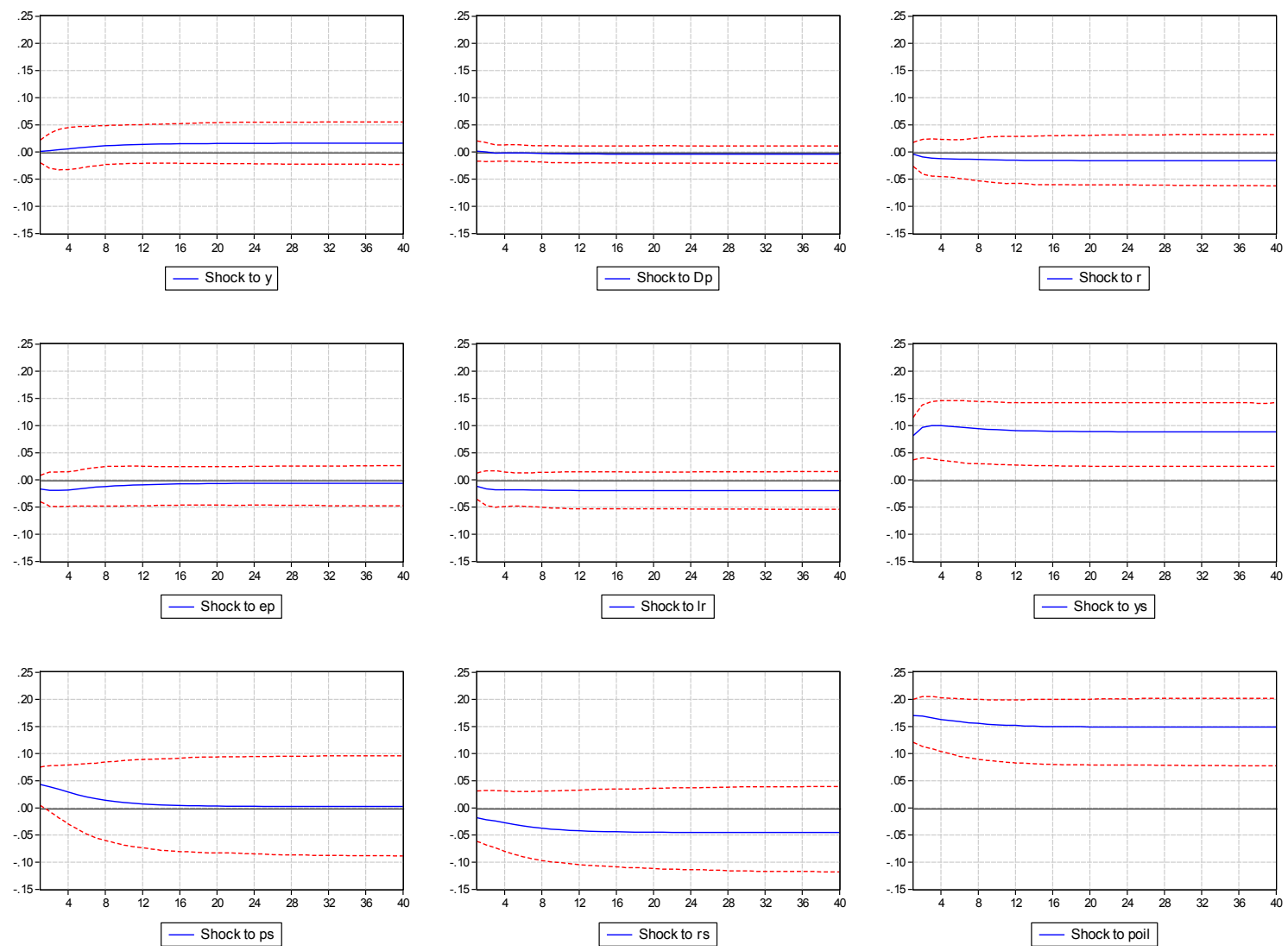


\section{Appendix C: The monetary transmission mechanism}

Bain and Howells (2003) defined the transmission mechanism of monetary policy as the "series of links between the monetary policy change and the changes in output, employment and inflation". This study considers a monetary policy change as a change in the official short-term interest rate at which the central bank lends money to the banking sector. This transmission process is summarised in Figure 22.

\section{Figure 22: The transmission mechanism of monetary policy}

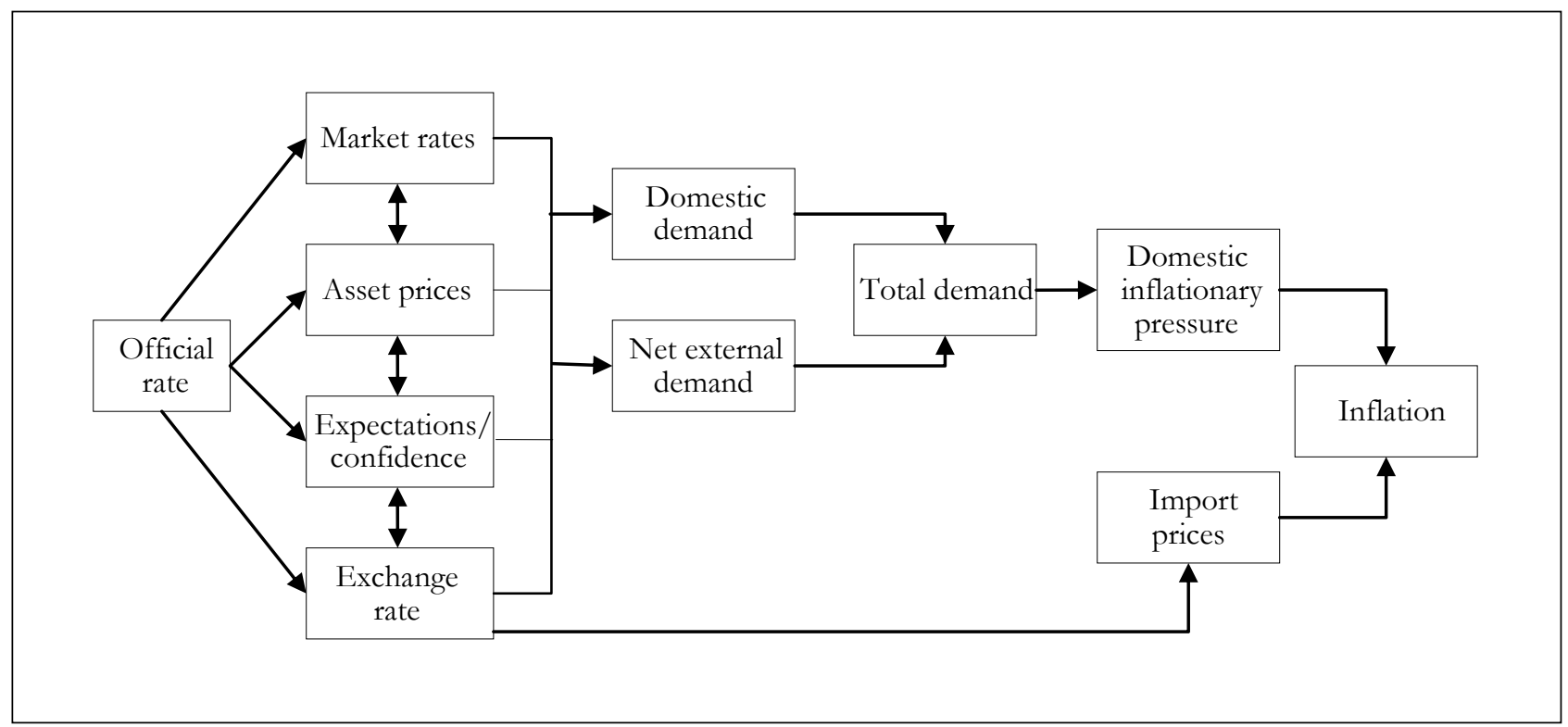

Source: Adapted from Bank of England (1999).

Figure 22 illustrates the various transmission mechanisms, or channels, through which changes in monetary policy affect the real economy and inflation in a country. Mishkin (1995) used the following categories to describe the transmission mechanisms: the interest rate channel, the exchange rate channel, other asset price channels and the credit channel. These channels are discussed below, for the most part using the categories chosen by Mishkin (1995) and the notation utilised by Smal and De Jager (2001).

Schematically the interest rate channel can be represented as follows:

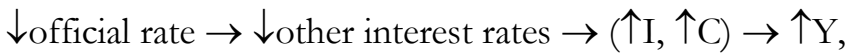

where $\downarrow_{\text {official rate }}$ shows an expansionary monetary policy through a decrease in the official short-term interest rate at which the central bank lends money to the banking sector. This causes other interest rates in the economy to decrease, which in turn increase fixed capital formation (I) and consumption spending (C), resulting in an increase in real economic output $(\mathrm{Y})$.

Changes in monetary policy also affect the real economy through the effect of exchange rate (ER) changes on net exports (NX). Lower domestic interest rates in comparison to interest rates in foreign countries depreciate the domestic currency, leading to an increase in net exports and thus in real economic activity. The exchange rate channel can be presented as follows:

$\downarrow_{\text {official rate }} \rightarrow \downarrow_{\text {other interest rates }} \rightarrow \downarrow$ ER $\rightarrow \uparrow \mathrm{NX} \rightarrow \uparrow \mathrm{Y}$

Mishkin (1995) furthermore showed how the monetary transmission mechanism works through other relative asset prices and real wealth. Schematic illustrations of the two other asset price channels are:

$\downarrow_{\text {official rate }} \rightarrow$ 个equity prices $\rightarrow \uparrow \mathrm{I} \rightarrow \uparrow \mathrm{Y}$ 
$\downarrow_{\text {official rate }} \rightarrow \uparrow$ prices of equity, property and land $\rightarrow \uparrow$ wealth $\rightarrow \uparrow \mathrm{C} \rightarrow \uparrow \mathrm{Y}$

The first of the above channels illustrates the transmission mechanism through other relative asset prices, where lower interest rates would increase equity prices and the attractiveness of investment spending according to Tobin's $q$ theory of investment (in Mishkin, 1995). The second channel shows the transmission mechanism through wealth effects on consumption, where the prices of previously acquired assets would increase due to lower interest rates, thereby increasing the wealth and consumption spending of the asset-holders.

The final channel is the credit channel. Mishkin (1995) separated the credit channel, which incorporates problems with asymmetric information and the expensive enforcement of contracts, into the bank-lending channel and balance-sheet channel. The bank-lending channel illustrates how a change in the official rate would change bank deposits, and hence bank loans to households and small firms as well as aggregate economic activity, in the opposite direction. This can be illustrated as follows:

$\downarrow$ official rate $\rightarrow$ 个bank deposits $\rightarrow$ ibank loans $\rightarrow(\uparrow \mathrm{I}, \uparrow \mathrm{C}) \rightarrow \uparrow \mathrm{Y}$

The balance-sheet channel specifically deals with the net worth of households and firms. As shown with the other asset price channels, an expansionary monetary policy causes an increase in equity prices, thereby increasing the net worth of households and firms. In addition, lower interest rates improve the cash flow position of households and businesses, as a result further increasing their net worth. Adverse selection and moral hazard problems are lower and lending increases, allowing higher consumption and investment spending. The schematic representation of the balance-sheet channel is:

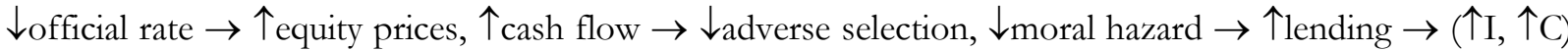
$\rightarrow \uparrow \mathrm{Y}$ 